\title{
A Review on Some Chemical Engineering and Microbiological Aspects Considered in the Production of Highly Concentrated Probiotic Cultures and Bacteriocins by Lactococci and Lactobacilli
}

\author{
Nelson Pérez Guerra \\ Nutrition and Bromatology Group, Department of Analytical and Food Chemistry, Food Science and Technology Faculty, \\ University of Vigo, Ourense Campus, As Lagoas s/n, 32004 Ourense, Spain
}

Correspondence should be addressed to Nelson Pérez Guerra, nelsonpg@uvigo.es

Received 15 August 2012; Accepted 10 October 2012

Academic Editors: A. Brucato and M. Hamdi

Copyright ( $\odot 2012$ Nelson Pérez Guerra. This is an open access article distributed under the Creative Commons Attribution License, which permits unrestricted use, distribution, and reproduction in any medium, provided the original work is properly cited.

The main purpose of this work is to give an overview on the chemical engineering aspects related with the production of probiotic cultures and bacteriocins. Firstly, some evidence of the potential of different Lactococci and Lactobacilli strains for prevention or treatment of different human diseases, or as growth promoters in farm animals is given. In addition, examples of different commercial dietary supplements containing probiotic lactoccocci and lactobacilli in combination or not with other probiotic bacteria are presented. Secondly, the main factors (cultivation method, culture media, and media composition) affecting the production of bacteriocins by lactoccocci and lactobacilli strains are showed. Examples of modelling procedures developed to describe the production of higher concentrations of biomass and bacteriocins in fed-batch cultures subjected or not to successive alkalizations are summarized. Finally, the corresponding mass balance equations performed in the latter cultures are presented to calculate the volumes of feeding substrates and the concentrations of nutrients (lactose, glucose, proteins, nitrogen, and phosphorous) added to the fermentation medium, as well as the concentrations of biomass and products in the fermentor just after each feeding.

\section{Main Characteristics of Probiotics}

Probiotics are viable microorganisms that, once ingested in sufficient amounts, exert health-promoting effects in humans and animals by assisting in the establishment of an intestinal population which is beneficial to the host entity and antagonistic to harmful bacteria [1-4].

This beneficial effect is commonly related with the elimination of pathogens by stimulating the immune system, by colonizing the gut in large numbers (competitive exclusion), and/or by the production of antimicrobial substances, including organic acids and bacteriocins $[5,6]$.

Thus, since the extensive use of antimicrobials (e.g., antibiotics and silver sulphadiazine) could produce adverse reactions and side effects $[7,8]$, the interest has been focussed on the use of probiotics for preventing or treating different human diseases $[1,4]$ and for improving the performance parameters of farm animals. These probiotics can play an important role in immunological, digestive, and respiratory functions in humans [9] and can improve the body weight gain and feed conversion in farm animals $[2,3]$.

The probiotic strains must be: (i) safe, noninvasive, nonpathogenic, nontoxic, and noncarcinogenic; (ii) resistant to gastric acidity and bile toxicity, which is an important characteristic for surviving and persisting in the stressful environment of the gastrointestinal tract; (iii) able to adhere to the host epithelial tissue (mucus and/or gut epithelial tissue), which is important to stimulate the immune system, prevent or reduce adhesion and colonization of pathogens and colonize the gut; (iv) amenable to industrial scale 
cultivation, which is important to obtain cultures with a high concentration of viable cells; (v) able to produce high amounts of antimicrobial substances (mainly organic acids, bacteriocins) antagonistic to pathogen growth; (vi) able to survive in delivery vehicles at the time of consumption to exert beneficial effects in the host; (vii) beneficial to the host in some way. Other desirable characteristics of probiotics are the resistance to spermicides (in the case of using probiotics for vaginal use), and the ability to influence metabolic activities such as cholesterol assimilation, lactase activity, and vitamin production $[2,9-14]$.

The most commonly used probiotics are some strains of Lactobacillus and Bifidobacterium, the yeast Saccharomyces cerevisiae, and the bacterium Bacillus subtilis [3, 4]. These strains have been used in combination or not with other bacteria to formulate different nutritional supplements, which are commercialized by some companies and suppliers (Table 1).

According to the manufacturers, these probiotic products are purported to maintain healthy intestinal flora, treat oral, throat and vaginal infections, enhance the body's natural defenses, assist intestinal functioning, adhere and colonize intestinal tract and stimulate intestinal immune response, enhance digestion and absorption of nutrients from food and other supplements, and reduce the length and severity of antibiotic-associated diarrhea, among other benefits [15].

1.1. Probiotic Effects of Lactic Acid Bacteria (LAB) in Humans and Animals. Some studies have shown the inefficacy of probiotic LAB to treat human diseases [16-20] and in a few cases, some of these bacteria have been associated with various types of infections, especially in severely ill or immunocompromised patients [19, 21-24]. However, in the latter case, the bacteria isolated from infectious sites were not always associated with consumed probiotic bacteria [21, 23, 25].

However, the results obtained in a great number of clinical studies have shown the beneficial effects of different probiotic LAB in human health and in addition, the numbers of infections associated with probiotics are scarce in comparison to the considerable and gradually increasing consumption of probiotics [23, 77].

Thus, bacteriotherapy with LAB strains have been assayed to prevent or treat diverse human diseases, including different types of diarrhea in adults and young children $[7,78-80]$, lactose intolerance [81-83], allergy caused by food consumption [84], infections of vagina, oral cavity, alimentary tract and urinary tract $[23,85-88]$, cancer $[89,90]$, irritable bowel syndrome [79, 91, 92], ulcerative colitis [93], and dermatitis [94].

Although these results indicate that the probiotics consumed in adequate amounts could produce health benefits, most of these studies have been carried out with rats, or with a reduced number of patients, or were not doubleblind, placebo-controlled trials and this may not guarantee the effectiveness of the treatment with the specific probiotic strains assayed [23]. Therefore, to prove the effectiveness of LAB in preventing or treating different human diseases before being commercialized, further research is needed by using a high number of patients and more randomized, double-blind, placebo-controlled trials [15].

As occurred in the clinical studies in humans, the results obtained on the efficacy of probiotic bacteria in treating diseases or in promoting growth in farm animals have been also contradictory [2, 95]. For example, some researchers observed that administration of probiotic bacteria to broilers did not produce a significant effect, but in weaned piglets, consumption of probiotic bacteria stimulated the growth and reduced the coliform counts of the animals [2, 96-99].

Thus, colonization of the gut by the probiotic bacteria, perhaps by a competitive exclusion mechanism [100], enhances development of both the intestinal epithelia and the gastrointestinal lymphoid system $[101,102]$ and supports the inherent defense mechanisms of a healthy intestinal tract, allowing a better control of intestinal pathogens [103]. In these conditions, the host consumes less energy to mobilize immune cells to fight pathogens [104] and consequently, the animal could gain weight quickly. But more often such effects are not significant, except when the animals are challenged with selected pathogenic strains or in gnotobiotic animals [95].

The different effect that the administration of probiotic bacteria produced in farm animals could be explained by the fact that probiotic effects are strain dependent $[2,20]$ and may also depend on the host and their immunologic state [20].

In the following paragraphs, some examples on the positive effects that administration of probiotics produced in both human and animals are presented.

\subsubsection{Some Examples of the Beneficial Effects of Lactococci and Lactobacilli in Humans and Animals}

\section{(1) Lactococcus Strains}

Lact. lactis subsp. cremoris FT4. Gobbetti et al. [105] investigated the production of Angiotensin-I-converting enzyme (ACE)-inhibitory peptides by fermentation of UHT skim milk with this strain. The results showed that the $\mathrm{IC}_{50}$ value of the crude purified fraction containing the peptide mixture was $8.0 \mathrm{mg} / \mathrm{L}$. The peptides were separated from fermented milk by reversed-phase fast-protein liquid chromatography. After purifying the fractions with the highest ACE-inhibitory indexes and sequencing the related peptides, the $\mathrm{IC}_{50}$ values increased to $193.9 \mathrm{mg} / \mathrm{L}$ (in case of the synthesized peptide $\beta$-CN f47-52) or higher than $1 \mathrm{~g} / \mathrm{L}$ (in case of the synthesized peptide $\kappa$-CN f152-160). According to these researchers, the synthesized inhibitory peptides were resistant to further proteolysis either during dairy processing or by trypsin and chymotrypsin.

Lact. lactis subsp. lactis HV219. Strain HV219, isolated from human vaginal secretions, produces a bacteriocin (bacHV219) with antibacterial activity against important pathogen bacteria including Enterococcus faecalis, Listeria innocua, Proteus vulgaris, and Pseudomonas aeruginosa [106, 107]. On the other hand, strain HV219 binds to Caco-2 cells. 
TAble 1: Some commercial products containing combinations of Streptococcus, Lactobacillus, Bifidobacteria, Lactococcus, Pediococcus, and Enterococcus strains [15].

\begin{tabular}{|c|c|c|}
\hline Manufacturer & Product & Strains \\
\hline \multirow{3}{*}{$\begin{array}{l}\text { NOW Foods: Nutrition for } \\
\text { Optimal Wellness }\end{array}$} & Acidophilus $4 \times 6$ Powder & $\begin{array}{l}\text { S. thermophilus, B. lactis (bifidum), B. longum, L. acidophilus, } \\
\text { L. bulgaricus, L. paracasei }\end{array}$ \\
\hline & Gr8-Dophilus & $\begin{array}{l}\text { S. thermophilus, B. bifidum, B. lactis, B. longum, } \\
\text { L. acidophilus, L. casei, L. rhamnosus, L. salivarius }\end{array}$ \\
\hline & Probiotic-10 25 Billion & $\begin{array}{l}\text { S. thermophilus, B. bifidum, B. breve, B. longum, } \\
\text { L. acidophilus, L. casei, L. paracasei, L. plantarum, } \\
\text { L. rhamnosus, L. salivarius }\end{array}$ \\
\hline $\begin{array}{l}\text { EFI: Essential Formulas } \\
\text { Incorporated }\end{array}$ & Dr. Ohhira’s Probiotics Original Formula & $\begin{array}{l}\text { S. thermophilus, B. breve subsp. breve, B. infantis subsp. } \\
\text { infantis, B. longum, E. faecalis TH10, L. acidophilus, L. brevis, } \\
\text { L. bulgaricus, L. casei subsp. casei, L. fermentum, L. helveticus } \\
\text { subsp. jugurti, L. plantarum }\end{array}$ \\
\hline \multirow{5}{*}{ Flora } & Udo's Choice Infant's Blend Probiotic & $\begin{array}{l}\text { S. thermophilus, B. bifidum, B. breve, B. infantis, } \\
\text { L. acidophilus, L. bulgaricus, L. casei }\end{array}$ \\
\hline & $\begin{array}{l}\text { Udo's Choice Children's Probiotic and } \\
\text { Udos Choice Adult's Probiotic }\end{array}$ & $\begin{array}{l}\text { S. thermophilus, B. bifidum, B. breve, L. acidophilus, } \\
\text { L. bulgaricus, L. casei, L. plantarum, L. rhamnosus }\end{array}$ \\
\hline & $\begin{array}{l}\text { Udo's Choice, Super } 8 \text { Hi-Potency } \\
\text { Probiotic }\end{array}$ & $\begin{array}{l}\text { S. thermophilus, B. bifidum, B. longum, } \\
\text { L. acidophilus, L. bulgaricus, L. plantarum, L. rhamnosus, } \\
\text { L. salivarius }\end{array}$ \\
\hline & Udo’s Choice Advanced Adult's Probiotic & $\begin{array}{l}\text { S. thermophilus, B. bifidum, B. breve, B. longum, } \\
\text { L. acidophilus, L. bulgaricus, L. casei, L. plantarum, } \\
\text { L. rhamnosus }\end{array}$ \\
\hline & Udo’s Choice Super 5 Lozenge Probiotic & $\begin{array}{l}\text { S. thermophilus, B. bifidum, L. acidophilus, L. bulgaricus, } \\
\text { L. salivarius }\end{array}$ \\
\hline Nature's Way & Primadophilus Optima & $\begin{array}{l}\text { S. thermophilus-110, B. breve-129, B. bifidum-132, B. } \\
\text { infantis-116, B. longum-135, L. acidophilus-122, L. } \\
\text { bulgaricus-137, L. casei-108, L. helveticus-128, L. } \\
\text { plantarum-119, L. rhamnosus-111, L. rhamnosus-114, L. } \\
\text { salivarius-118, Lact. lactis-136 }\end{array}$ \\
\hline \multirow[t]{3}{*}{ Sedona Labs } & iFlora Multi-Probiotic & $\begin{array}{l}\text { S. thermophilus, B. bifidum, B. breve, B. lactis (infantis), } \\
\text { B. lactis HN019, B. longum, L. acidophilus, L. brevis, } \\
\text { L. bulgaricus, L. casei, L. gasseri, L. paracasei, L. plantarum, } \\
\text { L. rhamnosus, L. salivarius, Lact. lactis }\end{array}$ \\
\hline & iFlora Nasal Sinus Support & S. thermophilus, B. bifidum, L. acidophilus, L. rhamnosus \\
\hline & iFlora Woman Multi-Probiotic & $\begin{array}{l}\text { S. thermophilus, B. lactis, L. acidophilus, L. bulgaricus, L. casei, } \\
\text { L. rhamnosus }\end{array}$ \\
\hline Sigma-Tau Pharmaceuticals & VSL \#3 & $\begin{array}{l}\text { S. salivarus subsp. thermophilus, B. breve, } B \text {. infantis, } \\
\text { B. longum, L. acidophilus, L. delbrueckii subsp. bulgaricus, } \\
\text { L. paracasei, L. plantarum }\end{array}$ \\
\hline Italfarmaco, S.A. & Prodefen & $\begin{array}{l}\text { S. thermophilus } \mathrm{PXN} 66, \text { B. breve PXN25, B. infantis PXN27, } \\
\text { L. acidophilus } \mathrm{PXN} 35, \text { L. bulgaricus PXN39, L. casei PXN37, } \\
\text { L. rhamnosus PXN54 }\end{array}$ \\
\hline \multirow{4}{*}{ Jarrow Formulas } & Jarro-Dophilus EPS & $\begin{array}{l}\text { B. breve R0070, B. longum BB536, L. casei } \mathrm{R} 0215, \text { L. helveticus } \\
\text { (L. acidophilus) R0052, L. plantarum } \mathrm{R} 1012 \text {, L. rhamnosus } \\
\text { R0011, Lact. lactis subsp. lactis } \mathrm{R} 1058, \text { Ped. acidilactici } \mathrm{R} 1001\end{array}$ \\
\hline & Jarro-Dophilus + FOS & $\begin{array}{l}\text { B. lactis BI-04, B. longum BB536, L. acidophilus LA-14, } \\
\text { L. casei } \mathrm{R} 0215 \text {, L. plantarum R1012, L. rhamnosus R0011 }\end{array}$ \\
\hline & Jarro-Dophilus Allergen-Free & $\begin{array}{l}\text { B. breve BR- } 03 \text {, B. lactis BS- } 01 \text {, L. acidophilus LA- } 02 \text {, } \\
\text { L. paracasei LPC- } 00 \text {, L. plantarum LP- } 01 \text {, L. rhamnosus LR- } 04\end{array}$ \\
\hline & Ultra Jarro-Dophilus & $\begin{array}{l}\text { B. breve Bb-03, B. lactis BI- } 04 \text {, B. longum BB } 536 \text {, } \\
\text { L. acidophilus La-14, L. casei Lc- } 11 \text {, L. paracasei Lpc- } 37, \text { L. } \\
\text { plantarum Lp-115, L. rhamnosus R0011, L. salivarius Ls-33, } \\
\text { Lact. lactis LI-23 }\end{array}$ \\
\hline
\end{tabular}


However, growth of this bacterium 19 decreased, respectively, by $42 \%$ and $71 \%$ in MRS media containing concentrations of oxbile of $0.3 \%$ or $0.6 \%(\mathrm{w} / \mathrm{v})$ in comparison with its growth in MRS medium without oxbile during $10 \mathrm{~h}$ of incubation. In addition, Lact. lactis subsp. lactis HV219 grew well at $\mathrm{pH}$ values between 6 and 11, but not at pH values between 3 and 5 [107]. Since the tolerance to low $\mathrm{pH}$ and resistance to high concentrations of bile salts are necessary requirements to survive the gastrointestinal tract conditions, administration of strain HV219 to humans should be carried out by using protective agents (e.g., mucin, whey proteins concentrate) [108] to ensure that a great number of probiotic cells could reach and colonize the gut.

Lact. lactis subsp. lactis CECT 539. A potentially probiotic additive containing both live cells of strain CECT 539 (PPA539) and its antimicrobial metabolites was evaluated as a replacement for antibiotics in diets for weanling pigs [2] and chickens [109]. This strain displayed many of the probiotic properties because this bacterium: (i) was capable of surviving in vitro, the conditions of the gastrointestinal tract, (ii) produced relatively high amounts of biomass and antimicrobial products (nisin, lactic and acetic acids) in whey media, (iii) showed a good viability after 3 months of storage at $-20^{\circ} \mathrm{C}$ with skim milk and in the piglet feed during its storage at room temperature for 8 days.

Addition of this lactic acid bacterium to a piglet fed produced a significant increase in body weight gain and final body weight and a reduction in the total coliform population of the animals, in comparison with the group fed a diet without probiotic [2]. The observed probiotic effect of this strain in piglets could be related to: (i) the reduction or inhibition of the proliferation of coliform and pathogenic bacteria, due to the production of antimicrobial substances (mainly nisin and organic acids), (ii) an inhibition of the adhesion of coliform and pathogenic bacteria to host cells, and/or (iii) a more rapid clearance of enteropathogens by and elevated immune response, either specific or innate, resulting from probiotic treatment [110-113].

However, administration of diets containing PPA539 to medium-growth Sasso X44 or Ross 308 broiler chickens did not produce the positive effects observed in weaned piglets [109].

\section{(2) Lactobacillus Strains}

L. acidophillus DDS-1. This acidofilin-producing strain [114] also produces lactase, lipases, and proteases, thereby helping alleviate symptoms associated with lactose intolerance and enhancing the digestion of proteins [115] and fats [116]. In addition, strain DDS-1 reduces serum cholesterol [117] and suppresses Helicobacter pylori growth [118].

Other studies showed the ability of L. acidophilus DDS1 for preventing tumor formation in rats challenged with a chemical carcinogen [119] and inducing the production of higher levels of immunologic factors (interleukin-1 alpha and tumor necrosis factor-alpha), which are known to have potent cytocidal and cytostatic effects on tumor cells [120].
According with other researchers [121], strain DDS-1 was able not only to adhere onto human enterocyte like Caco- 2 cells in culture, but this LAB also strongly binds to the mucus secreted by the homogeneous cultured human goblet cell line HT29-MTX. This bacterium also inhibited, in a dose-dependent manner, the cell association of enterotoxigenic, diffusely adhering and enteropathogenic Escherichia coli and Salmonella typhimurium and the cell invasion by enteropathogenic E. coli, Yersinia pseudotuberculosis, and Salm. typhimurium. Furthermore, it was observed that the spent culture supernatant of strain DDS-1 produced antibacterial activity in vitro, against important pathogens, such as Staphylococcus aureus, L. monocytogenes, Salm. typhimurium, Shigella flexneri, Klebsiella pneumoniae, P. aeruginosa, and Enterobacter cloacae [122].

Different probiotic products containing strain DDS-1 (e.g., Dr. Shahani's L. acidophilus, DDS 100 Acidophilus capsules) or a combination of it with Bifidobacterium strains (e.g., DDS - Multi-Flora ABF: Probiotic for adults, DDS Plus 3, BioPRO) have been marketed worldwide [117]. According to the manufacturers, the use of these probiotic preparations improves digestive health, supports healthy cholesterol levels, and enhances immune function among others benefits.

L. acidophillus KFRI34. Chang et al. [123] tested the potential of this strain as an inhibitor of 1,2-dimethylhydrazine(DMH-) induced symptoms in live rats F344, which were randomly distributed into three groups of 15 animals. The first group (control) received a high-fat diet, the second group was administered with a high-fat diet containing a potent colon carcinogen (DMH), and the third group fed a high-fat diet containing the carcinogen plus L. acidophilus KFRI342. The results obtained showed that consumption of this bacterium decreased the number of $E$. coli in faecal samples, the enzyme activities of $\beta$-glucuronidase and $\beta$ glucosidase, and the plasma triglyceride concentration in comparison to the groups that consumed diets without strain KFRI342. According with these results, the authors [123] concluded that L. acidophillus KFRI34, which was isolated from the Korean traditional food kimchi, showed potential probiotic activity as an inhibitor of $\mathrm{DMH}$-induced symptoms in live rats. These researchers also suggest that this strain may be suitable as a probiotic for human use.

L. acidophillus La-5. Studies with this strain have been commonly carried out by using this lactacin B producer bacterium [124] in combination with other LAB or with other treatments. For example, administration of Trevis capsules (Chr. Hansen, Denmark, containing $4 \times 10^{9}$ colony forming units (CFU) of strains La-5, B. lactis BB-12, Streptococcus thermophilus and L. bulgaricus) and a prebiotic (oligofructose) produced a reduction in the gastric colonization with multiple organisms and potentially pathogenic bacteria in critically ill patients [125]. However, the intestinal permeability, the systemic inflammatory response, septic morbidity, mortality, or length of hospital stay were not affected after administration of these probiotic strains.

The effect of the treatment with the probiotic AB-Cap10 , which contained a mixture of strains La-5 and BB-12 
(Chr. Hansen A/S, Denmark), was investigated for 12 weeks in Danish patients with collagenous colitis, a chronic inflammatory bowel disease, which is characterised by chronic watery diarrhea and distinct histopathological changes [126]. Twenty-nine patients were in a multicenter, double-blind, placebo-controlled study randomized: 21 individuals to the probiotic $\mathrm{AB}$-Cap-10 group and 8 individuals to the placebo group. The results obtained showed that administration of the probiotic capsules containing $0.5 \times 10^{9} \mathrm{CFU}$ of each bacterium ( 2 capsules twice daily), reduced significantly the bowel frequency from 32 to 23 weeks, as well as the number of days (from 6 to 1 day) with liquid stools per week. The treatment also produced an increase in the number of days with solid stools per week. Taking into account these results, the researchers indicated that the probiotic treatment with the strains La- 5 and BB-12 can have a therapeutic effect on the disease course of collagenous colitis [126].

In the same way, Reddy et al. [127] designed a randomized clinical trial to investigate whether the gut microflora can be modulated and the intestinal barrier function can be preserved in patients undergoing colectomy by using a combination of mechanical bowel preparation, neomycin and a symbiotic (Trevis capsules plus oligofructose powder). The results obtained showed that consumption of this combination reduced significantly the prevalence of faecal Enterobacteriaceae allowing a selective decontamination of the gut microflora, and contributing to the preservation of the intestinal barrier function. However, these researchers consider that these effects were not associated with a diminution in the systemic inflammatory response or septic morbidity.

Administration of a probiotic yogurt containing strains La-5 and BB-12 to patients infected with either antibioticsensitive or -resistant $H$. pylori reduced significantly both the residual pathogen loads despite antimicrobial resistance $[128,129]$ and increased the efficacy of the quadruple therapy (amoxicillin-metronidazole-omeprazole-bismuth subcitrate) in eradicating residual $H$. pylori [129]. Another study showed that the administration of the same probiotic yogurt to type 2 diabetic individuals produced a decrease in the total cholesterol and low-density lipoprotein cholesterol, suggesting that consumption of this probiotic yogurt may contribute to the improvement of cardiovascular disease risk factors [130].

L. acidophillus 145. Glück and Gebbers [131] conducted a randomized, open and prospective trial to assess the efficiency of fermented milk drink (containing Lactobacillus GG (ATCC 53103), Bifidobacterium sp. B420, L. acidophilus 145, and $S$. thermophilus) in reducing the occurrence of potentially pathogenic bacteria in the nasal cavity. In the study, 108 volunteers were fed with the fermented milk drink and 101 volunteers consumed a standard yogurt (produced with $S$. thermophilus and L. delbrueckii subsp. bulgaricus) daily for 3 weeks. The administration of fermented milk drink significantly reduced the occurrence of potentially pathogenic bacteria (Staphylococcus aureus, S. pneumonia, and $\beta$ hemolytic streptococci) in the upper respiratory tract of patients who consumed the probiotic drink in comparison to the group who consumed yogurt.

In another study with nine women (aged 22-43 years), Oberreuther-Moschner et al. [132] found that the dietary supplementation with a probiotic yogurt (standard yogurt produced with Lact. lactis and S. thermophilus but enriched with the probiotic strains L. acidophilus 145 and B. longum 913) significantly reduced both the genotoxicity of human fecal water and the overall genetic damage in comparison with supplementation of the standard yogurt without probiotics.

L. acidophilus NAS. Metts et al. [133] explored the effect of $L$. acidophilus NAS in the reduction of recurrent candidal vulvovaginitis in female university students. This randomized, double-blind, placebo-controlled trial for an average 3.3months was designed for 27 women who had recent vaginitis or vulvovaginal infections in the 12 months previous to the experiment. The first group (9 women) received the preparations $L$. acidophilus, strain NAS vaginal suppositories $\left(2 \times 10^{9} \mathrm{CFU} /\right.$ capsule, from Gy-Na-tren $)$ and placebo oral capsules containing $\sim 300 \mathrm{mg}$ cellulose (Solka-Floc). The second group ( 8 women) received the L. acidophilus, strain NAS vaginal suppositories and oral probiotic capsules containing (L. acidophilus NAS $\left(5 \times 10^{9} \mathrm{CFU} /\right.$ capsule), B. bifidum strain Malyoth $\left(2 \times 10^{10} \mathrm{CFU} /\right.$ capsule) and L. bulgaricus LB-51 $(5 \times$ $10^{9} \mathrm{CFU} /$ capsule) from Healthy Trinity). The control group (10 women) received placebo preparations vaginally and orally. Results from this study showed a significant reduction in the incidence of candidal vulvovaginitis in women with recurrent infections due to the use of vaginal inserts of $L$. acidophilus NAS, with or without oral probiotic capsules.

L. acidophilus NCFM. This strain has been widely used in commercial foods including milk, yogurt and formulas for children, dietary supplements, and juices, due to its important probiotic properties [134]. In this way, Gilliland and Speck [135] observed that this lactacin B-producing strain produced antibacterial activity against important foodborne disease bacteria including Stap. aureus, Salm. typhimurium, enteropathogenic E. coli, and Clostridium perfringens. Different researchers $[136,137]$ have reported that this LAB is safe, amenable to commercial manipulation, capable of adhering to human fetal intestinal cells and Caco-2 cells and mucus-secreting HT-29 cell culture systems. In addition, strain NCFM exhibited a good stability during frozen storage at $-20^{\circ} \mathrm{C}$ for 6 weeks [138] and survived gastrointestinal tract transit [139].

Different health effects in animal and human models have been reported before for this strain. Thus, Goldin and Gorbach [140] observed a reduction in the colon cancer incidence in rats receiving L. acidophilus NCFM after a 20-week induction period in animal studies. Oral administration of strain NCFM has been shown to induce the expression of mu-opioid and cannabinoid receptors in intestinal epithelial cells, and produce an analgesic effect (reducing pain) in the gut similar to that produced by the morphine [141]. According to the researchers, these results suggest new 
approaches for the treatment of abdominal pain and irritable bowel syndrome.

In humans, consumption of milk containing strain NCFM improved lactose digestion lactose in lactose-intolerant patients $[81,82]$. On the other hand, a combination of probiotic strains (L. acidophilus NCFM, $L$. reuteri, and B. infantis BBI) has been reported to decrease the risk of diarrhea in young children as well as the levels of toxic amines in the blood of dialysis patients with small bowel bacterial overgrowth [134].

L. acidophilus ATCC 4356. Ryan et al. [142] investigated the anti- $H$. pylori activity of 28 strains of $L$. salivarius and 12 other lactobacilli (including L. acidophilus ATCC 4356), isolated from different sites and from different geographical regions. The results showed that strain ATCC 4356 inhibited the growth of the pathogen, indicating that this lactic acid bacterium could be used as an adjunct in the treatment of diseases (gastritis, gastric and duodenal ulcer, and gastric cancer) caused by the antibiotic resistant $H$. pylori [142].

L. acidophilus $L B$. This strain, isolated from human stool, was able to adhere well to the brush border of differentiated human intestinal epithelial Caco-2 cells in culture [143] and was also capable of inhibiting, depending on the concentration, cell attachment and invasion of Caco- 2 cells by the enterovirulent bacteria Yersinia pseudotuberculosis and $L$. monocytogenes [144]. In addition, it has been shown that the spent culture supernatants of this strain reduced, in vitro, both the viability of $H$. pylori strain 1011 and the adhesion of the pathogen to the cultured human mucosecreting HT29MTX cells [145]. The same researchers reported that oral administration of strain LB in combination with its spent culture supernatant (SCS) inhibited $\mathrm{H}$. felis CS1 colonization and decreased urease activity in conventional specificpathogen-free $\mathrm{BALB} / \mathrm{c}$ mice [145].

In addition, it has been reported that the SCS from $L$. acidophilus LB efficiently decreased transcellular passage of Salm. enterica serovar Typhimurium, inhibited the intracellular growth of the pathogen, and also inhibited adhesiondependent serovar typhimurium-induced interleukin-8 production in Caco-2/TC-7 cells [146]. Another study [147] showed that $L$. acidophilus LB and its antimicrobial activity produced a protective effect against the brush border lesions promoted by the diarrhoeagenic E. coli (Afa/Dr DAEC) strain C1845 in human enterocyte-like cells.

Moal et al. [148] designed an experimental study and a randomized, double-blind, placebo-controlled clinical trial in 80 children (male or female, 10 months of age, who had nonrotavirus, acute, watery diarrhea) to evaluate the antisecretory activity of strain LB against nonrotavirus diarrhea. The results obtained showed that addition of a pharmaceutical preparation (Lactéol Fort sachet, Laboratoire du Lactéol) that contains $10^{9}$ heat-killed L. acidophilus LB plus $160 \mathrm{mg}$ of spent culture medium to a solution of oral rehydration shortened by one day the time until the first normal stool was passed, as compared with children who received placebo oral rehydration solution (PORS). In addition, the diarrhea was resolved in a significantly higher proportion of children in the group receiving the probiotic strain than in the group receiving the PORS. With regard to the consistency of the stools, the researchers observed an improvement in the stool consistency in the probiotic group, whereas the stools of the children of the PORS group tended to remain fluid or semifluid [148].

L. bulgaricus Strains. Bodana and Rao [149] investigated the antimutagenic activity of milk fermented by S. thermophilus, L. bulgaricus and a combination of both bacteria by using Salm. typhimurium strains TA 98 and TA 100 and the mutagens 4-nitroquinoline-N-oxide (a direct-acting mutagen) and 2-aminofluorene (a mutagen requiring $\mathrm{S} 9$ activation). The results showed that the extracts obtained from all the fermented milks significantly suppressed the number of revertants caused by the two mutagens in strains TA 98 and TA 100, but extracts from unfermented milk did not show antimutagenic activity. In addition, extracts obtained from milk fermented by L. bulgaricus plus S. thermophilus showed a more effectiveness in deactivating etiologic risk factors of colon carcinogenesis than the extracts prepared from milk fermented by S. thermophilus alone.

Martini et al. [150] conducted a randomized, doubleblind study with a yogurt containing a mixture of $S$. salivarius subsp. thermophilus and L. delbrueckii subsp. bulgaricus and fermented milks containing individual species of $S$. thermophilus, L. delbruekii subsp. bulgaricus, L. acidophilus, or B. bifidus) with different levels of $\beta$-galactosidase activity to evaluate their ability to improve lactose digestion in lactose maldigester. Although the researchers observed that all yogurts highly and similarly improved lactose digestion, the best results were obtained with milks fermented with $L$. bulgaricus.

As it was described above for Lact. lactis subsp. cremoris FT4, L. delbrueckii subsp. bulgaricus SS1 was found to produce high amounts of ACE-inhibitory peptides during fermentation of UHT skim milk [105]. Thus, the $\mathrm{IC}_{50}$ value of the most inhibitory crude purified fractions containing the peptide mixtures were 10.3 and $11.2 \mathrm{mg} / \mathrm{L}$. However, the $\mathrm{IC}_{50}$ values of the synthesized peptides were $179.8 \mathrm{mg} / \mathrm{L}$ (in case of $\beta$-CN f73-82) and $290.7 \mathrm{mg} / \mathrm{L}$ (in case of $\beta$-CN f6-14).

On the other hand, Kitazawa et al. [151] observed that the DNA from L. delbrueckii subsp. bulgaricus NIAI B6 can stimulate a significant proliferation of certain immune cells (peyer's patch and splenic B cells) in vitro. According to these researchers, this result suggests that the probiotic strain could modulate local immunity in vivo via the stimulation of lymphoid tissues within the gut.

Bai et al. [152] investigated the effect of L. bulgaricus LB10 on interleukin-8 secretion in intestinal epithelia when stimulated by proinflammatory cytokines. The results obtained in this study indicated that when preincubated with strain LB10, HT29 cells produced less interleukin-8 $(515.4 \pm 55.4 \mathrm{ng} / \mathrm{L})$, compared with the production obtained $(639.5 \pm 62.3 \mathrm{ng} / \mathrm{L})$ when HT29 cells where preincubated with tumor necrosis factor $(\mathrm{TNF}-\alpha)$. This indicates that strain LB10 has a great potential for suppressing inflammatory 
immune reactions in the intestinal walls that produce tissue damage.

Hickson et al. [80] designed a randomised double-blind placebo controlled study with hospital patients (mean age 74) taking antibiotics to determine the efficacy of a probiotic yogurt (Actimel, Danone, France, containing L. casei, L. bulgaricus, and $S$. thermophilus) in preventing antibiotic and Clostridium difficile associated diarrhea. The authors concluded that routine consumption of the probiotic drink could help to reduce the incidence of the two types of diarrhea and decrease morbidity, health care costs, and mortality in patients aged over 50 .

L. casei subsp. casei CECT 4043. Two studies with weaned piglets [2] and broiler chickens [109] were designed to assay the effects of a potentially probiotic preparation containing live cells of strain CECT 4043 and its fermentation products (PPA4043) on performance and coliform counts of the animals.

In the first study, the 20 weaned piglets receiving PPA4043 had significantly higher body weight gain, final body weight and feed conversion values and lower coliform counts than the group receiving a diet without probiotic during 42 days of supplementation [2]. Based on these results, the same research group designed a new experiment to study the effect of consumption of PPA4043 during both the administration ( 1 to 28 days) and postadministration periods. In this assay, 40 piglets were administered with PPA4043 for 28 days and subsequently the animals received the basal diet without probiotics until the 42nd day of the experiment [3]. At the end of the administration period (day 28), the group receiving PPA4043 had a body weight gain significantly higher than that of the control group, although the mean feed intake and feed conversion efficiency values in the two groups were similar. For the whole experimental period (42 days), the control group presented the lowest feed intake value and the probiotic group exhibited the highest feed conversion efficiency value. However, no significant difference in body weight gain was observed between the probiotic and the control groups.

Interestingly, fecal coliform values decreased (although not significantly) by day 28 in the PPA4043 group, but returned to pretreatment levels by day 42 . This result suggests that the strain CECT 4043 was unable to colonize and persist in the gastrointestinal tract of the animals in the postadministration period [3] and was progressively replaced by the bacteria of the intestinal microflora once probiotic administration stopped [5, 153-155].

The following experiments were conducted with medium-growth Sasso X44 chickens housed in cages and with nutritional stressed Ross 308 broiler distributed in pens [109]. Consumption of the probiotic diet containing PPA4043 or unsupplemented (control) diet did not affect significantly the growth performance and final coliform counts in Sasso X44 chickens after 42 days of administration. However, counts of lactic acid bacteria and mesophilic microorganisms were significantly higher in the animals receiving PPA4043 than in the control group. In the experiment with nutritional stressed Ross 308 broiler, although no differences in body weight gain were observed between treatments, the feed conversion efficiency was lower in the probiotic group, indicating that these broilers were the most efficient at converting feed into live weight.

L. casei Strain Shirota. Aso and Akazan [89] conducted a randomized controlled study in 58 patients with superficial bladder cancer in order to investigate the safety of an orally administered ( $3 \mathrm{~g} /$ day) Lactobacillus preparation (Biolactis powder (BLP), a freeze-dried preparation of $L$. casei strain Shirota cells) and its preventive effect on the recurrence after transurethral resection of the bladder tumor.

In addition, Aso et al. [90] developed a double-blind trial with 138 patients with superficial transitional cell carcinoma of the bladder following transurethral resection to evaluate the prophylaxis of recurrence by BLP. The subjects were distributed into three groups of patients with primary multiple tumors (first group); with recurrent single tumors (second group); with recurrent multiple tumors (first group), which were randomly allocated to receive BLP or placebo. The results showed that in the first two goups, BLP showed a better prophylactic effect than placebo, but consumption of BLP or placebo in the third group did not produce significant differences. According to the results from both studies $[89,90]$, the oral administration of BLP was a safe and effective way for preventing the recurrence of superficial bladder cancer.

Another study [156] showed that supplementation of L. casei Shirota strain YIT9029 to Wistar rats previously infected with $L$. monocytogenes significantly reduced the counts of the pathogen in stomach, caecum, faeces, spleen and liver, 2 days after infection. The authors concluded that oral administration of strain YIT9029 enhances the host response against oral L. monocytogenes infection in the rats, probably due to increased cellular-mediated immunity.

A double-blind, placebo-controlled, randomized study was conducted over a four-week period in 70 patients with symptoms of chronic constipation by Koebnick et al. [157] to investigate the effect of a probiotic beverage (containing $6.5 \times 10^{9} \mathrm{CFU}$ of L. casei strain Shirota) on gastrointestinal symptoms in patients with chronic constipation. The results indicated that consumption of the probiotic strain produce a beneficial effect on the gastrointestinal symptoms of the patients, as demonstrated by a significant improvement in stool consistency and bowel movement frequency. According to these researchers, these positive effects could be associated with changes in the microflora and the intestinal milieu.

On the other hand, the results obtained by Sgouras et al. [158] showed that $L$. casei strain Shirota obtained from the fermented milk product Yakult (Yakult Ltd., Tokyo, Japan) inhibited the growth of $H$. pylori SS1 and nine H. pylori clinical isolates in vitro and in vivo experiments in an animal model. In the latter study, the authors observed a significant reduction in the levels of $H$. pylori colonization in the antrum and body mucosa and in the associated chronic and active gastric mucosal inflammation observed at each sampling time over 9 months.

Takeda and Okumura [159] studied the effect of consumption of a fermented milk drink (Yakult 400) containing 
L. casei strain Shirota on the human natural killer (NK) cell activity. In this study, nine healthy middle-aged and 10 elderly volunteers with had relatively low levels of NK-cell activity, drank fermented milk containing $4 \times 10^{10} \mathrm{CFU}$ of $L$. casei strain Shirota daily for $3 \mathrm{wk}$. The results demonstrated that habitual consumption of the fermented milk provides a positive effect on NK-cell activity, since increased and maintained NK-cell activity in middle-aged and in elderly individuals, respectively.

L. casei CRL431. This bacterium, isolated and characterized in the Reference Center for Lactobacilli (CERELA-CONICET, Tucuman, Argentina), has been used in different studies in animal and human models [160].

In this way, Gaon et al. [161] conducted a randomized, double-blind, placebo-controlled study to evaluate the efficacy of an oral probiotic preparation of 2 viable lyophilized strains of lactobacilli (L. casei and L. acidophillus strains CERELA) compared with placebo, in 22 patients with proven overgrowth and chronic diarrhea. Subjects were divided into a group of 12 patients, which received identical capsules with both $L$. casei and L. acidophillus strains CERELA and a group of 10 patients, which received the placebo during three consecutive periods of 7 days each followed by a similar three periods of control after withdrawal. The mean daily number of stools, glucose breath $\mathrm{H} 2$ test, and symptoms were evaluated at the end of each period. The results showed that consumption of Lactobacillus strains led to a significant reduction in mean daily number of stools and in bacterial overgrowth-related chronic diarrhea as compared with the placebo group.

Later, Gaon et al. [162] implemented a randomized, double-blind, placebo-controlled study to investigate the effect of of Lactobacillus strains and Saccharomyces boulardii on persistent diarrhea in children aged 6-24 months. The patients (eighty-nine children) were distributed into three groups of 29,30 , and 30 children to receive placebo, which consists of pasteurized cow milk (first group), lyophilized Sacch. boulardii $\left(10^{10} \mathrm{CFU} / \mathrm{mL}\right.$ of suspension) suspended in pasteurized cow's milk (second group), or pasteurized cow's milk containing lyophilized L. casei $\left(10^{10} \mathrm{CFU} / \mathrm{g}\right)$ and L. acidophillus ( $10^{12} \mathrm{CFU} / \mathrm{g}$ ) strains CERELA (third group). The diets were administered twice daily, at a dose of $175 \mathrm{~g}$ during 5 days. At the end of the study, the researchers observed that the administration of lactobacilli and Sacch. boulardii significantly reduced the number of depositions, diarrheal duration and vomiting in comparison with the placebo group.

In another study, de Vrese et al. [83] explored the effect of probiotic (L. rhamnosus GG or L. acidophilus CRL431) administration in the immune response to a standardized enterovirus challenge (polio) and infections not limited to the gastrointestinal tract in 64 healthy adults. Results from this randomized, controlled, and double-blind study showed that consumption of both probiotic strains increased poliovirus neutralizing antibody titers and affected the formation of poliovirus-specific $\operatorname{IgA}$ and $\mathrm{IgG}$ in serum. Taking into account these results, the researchers concluded that administration of these strains induces an immunologic response that may result in an enhanced systemic protection of cells from virus infections.

Maldonado and Perdigón [163] studied the effect of oral administration of L. casei CRL431 ( $10^{8} \mathrm{UFC} / \mathrm{mL} / \mathrm{mouse} /$ day $)$ on the expression of receptors involved in the innate immune response using $\mathrm{BALB} / \mathrm{c}$ mice (6 weeks of age). The results obtained showed that the interaction between this strain and the immune cells associated with the gut induces an increase in the number of CD-206 and Toll-like receptor-2 receptors in the cells implicated mainly in the innate immune response.

L. paracasei NCC2461 (ST11). Although most of the studies with this strain have been carried out in animal models, the positive effect of consumption of this bacterium has been also observed in humans.

Thus, in a study carried out with female 6-week-old $\mathrm{BALB} / \mathrm{c}$ and C57BL/6 mice, different lactobacilli (L. johnsonii NCC533, L. gasseri NCC2493, L. paracasei NCC2461, L. acidophilus NCC90, L. casei strain Shirota, and L. casei strain GG) were tested for their capacity to induce the secretion of IL-12 and IL-10 after 24 h of culture with BALB/c splenocytes [164]. Although all lactobacilli induced the secretion at various levels of both IL-12 and IL-10 in murine splenocytes, strain NCC2461 was the best inducer. In addition, strain NCC2461 strongly inhibited the proliferation of $\mathrm{CD}^{+} \mathrm{T}$ cells, as well as the secretion of Th1 and Th2 effector cytokines, but induced, in a dose-dependent manner, the secretion of transforming growth factor $\beta$.

In addition, another study showed that administration of L. paracasei NCC2461 in spent culture medium attenuates antibiotic induced visceral hypersensitivity in mice [165].

A randomized, double-blind, placebo-controlled clinical trial showed that administration with this strain $\left(10^{10} \mathrm{CFU}\right.$, daily for 5 days) significantly reduced the cumulative stool output, stool frequency, and oral rehydration solution intake in children with less-severe nonrotavirus diarrhea [17]. On the other hand, administration of a diet containing strain NCC2461, arachidonic and docosahexaenoic acids, galactoand fructo-oligosaccharides to weaning mice can revert the negative imprinting of neonatal stress on both intestinal barrier function and growth [166].

L. plantarum 299v. Important and promising results have been obtained with the use of this strain for treating different human diseases has produced. For example, a study showed the ability of this bacterium to colonize children with human immunodeficiency virus and to elicit specific systemic immune responses after oral administration [167]. In addition, the results obtained by different researchers [168-170] indicated that administration with strain $299 \mathrm{v}$ allowed a reduction in pain, bloating and flatulence and a normalization of stools frequency in patients with irritable bowel syndrome.

In another study [171], administration of a freeze-dried preparation containing live L. plantarum 299v together with a substrate of oat fiber reduced the pancreatic sepsis and the number of surgical interventions related to pancreatic damage in patients with acute pancreatitis. In addition, the use of strain $299 \mathrm{v}$ in combination with fiber-containing solutions 
led to a decrease in the rate of postoperative infections in liver transplant recipients [172] or in patients with major abdominal surgery (gastric and pancreas resections) [173].

Experiments in animal models have also provided evidences on the positive effect of consumption of strain 229v. In this way, Mangell et al. [174] observed a suppression of the E. coli-induced increase in intestinal permeability, when Sprague-Dawley rats were administered with this bacterium.

L. reuteri ATCC 55730. Different studies indicated that consumption of this strain reduced significantly the episodes of diarrhea in children. In this way, Ruiz-Palacios et al. [175] explored the effect of this strain in preventing communityacquired diarrhea in 12 to 36 month-old children living in Mexico. For this purpose, the researchers conducted two blinded, controlled trials. The results obtained in both studies indicated that consumption of this bacterium alone (first study with 243 children for 14 weeks) or in combination with $L$. acidophilus and $B$. infantis (second study with 388 children for 16 weeks) reduced the incidence of diarrhea in children. The studies conducted by Shornikova et al. [176, 177] showed that consumption of strain ATCC 55730 significantly reduced the duration of watery diarrhea in young children between 6 and 36 months of age hospitalized with acute diarrhea (caused by rotavirus in $75 \%$ ) as compared with the group of patients receiving a placebo [176]. The increase in the administration dose ( $10^{7}$ to $\left.10^{10} \mathrm{CFU}\right)$ significantly shortened the duration of watery diarrhea associated with rotavirus [177].

Weizman et al. [178] explored the effect of probiotics ( $L$. reuteri ATCC 55730 and B. lactis Bb-12) in the occurrence of infections in 201 children aged 4-10 months during 12 weeks. The children were distributed into three groups to receive a humanized cow's formula supplemented with $1 \times$ $10^{7} \mathrm{CFU} / \mathrm{g}$ of formula powder of $L$. reuteri ATCC 55730 (first group, 68 children) or B. lactis Bb-12 (second group, 73 children). The third group (60 children) received placebo (the same formula without probiotics). The results obtained from this double-blind, placebo-controlled, randomized trial showed that consumption of probiotics (mainly L. reuteri ATCC 55730) reduced significantly the episodes of fever and diarrhea. In fact, the children belonging to the $L$. reuteri ATCC 55730 group required significantly fewer clinic visits, child care absences, and antibiotic prescriptions in comparison with the placebo and $B$. lactis $\mathrm{Bb}-12$ groups.

Lionetti et al. [179] explored wheter the addition of $L$. reuteri ATC 55730 to an anti-H. pylori regimen could help in the prevention or reduction of the gastrointestinal side effects burden in children. In this study, forty $H$. pylori-positive children (21 males; median age: 12.3 years) were treated with 10-day sequential therapy (omeprazole + amoxycillin for 5 days, and omeprazole + clarithromycin + tinidazole for other 5 days) and blindly randomized to receive either the probiotic strain $\left(10^{8} \mathrm{CFU}\right)$ or placebo. The results showed the efficacy of the probiotic treatment for reducing frequency and intensity of antibiotic-associated side effects during eradication therapy for $H$. pylori.

In a prospective randomized study conducted by Savino et al. [180] to test the effect of oral administration of strain ATCC 55730 in the treatment of infantile colic, the researchers observed a reduction in crying time within one week of treatment in comparison to the group of children receiving simethicone.

Other clinical studies with adults have showed the positive effects of administration of strain ATCC 55730 [181]. For example, consumption of this bacterium by healthy adult subjects ( $>18$ years of age) produced a significant colonization of the stomach, duodenum, and ileum. This was associated with significant alterations of the immune response in the gastrointestinal mucosa [181].

Nikawa et al. [182] investigated the effect of $L$. reuteri ATCC 55730 against S. mutans, one of the major cariogenic bacterium. The results showed that the lactic acid bacterium has a potent inhibitory effect on the growth of the pathogen in vitro. In addition, a double-blind, placebo-controlled trial conducted by the same researchers with 40 healthy female subjects (20 years old) showed that consumption of a milk fermented with $L$. reuteri ATCC 55730 significantly reduced the oral carriage of mutans streptococci, compared with the placebo yogurt, which was prepared with L. bulgaricus and $S$. thermophilus.

On the other hand, a complete eradication of $H$. pylori was observed in $60 \%(9 / 15)$ of the patients (aged 2556) suffering from dyspepsia caused by infection with the pathogen, which received omeprazole $(20 \mathrm{mg} /$ day $)$ plus $L$. reuteri ATC $55730\left(10^{8} \mathrm{CFU}\right.$ twice daily) in comparison with the placebo group, that received omeprazole $(20 \mathrm{mg} /$ day $)$ plus placebo [183].

Francavilla et al. [184] investigated the efficacy of the probiotic strain in the reduction of $H$. pylori intragastric load in vivo, dyspeptic symptoms, and in the eradication rates after conventional treatment. In this double-blind placebocontrolled study, $40 \mathrm{H}$. pylori-positive subjects (aged 3568 years old) were given chewable tablets containing $10^{8}$ CFU of L. reuteri ATCC 55730 (20 patients) or placebo (20 patients) once a day for 4 weeks. According with their results, the researchers concluded that $L$. reuteri administration can suppress $H$. pylori infection in humans and reduce the occurrence of dyspeptic symptoms, although this treatment did not affect antibiotic therapy outcome.

\section{Bacteriocin Production: Other Important Characteristic of LAB}

Mechanistic studies in laboratory assays or in animal models have shown that antibacterial substances (bacteriocins, $\mathrm{H}_{2} \mathrm{O}_{2}$, organic acids: lactic, acetic, and propionic acids) produced by some lactococci and lactobacilli inhibit the growth and survival of different pathogens (E. coli, Salm. typhimurium, Sh. sonnei, H. pylori, Campylobacter jejuni, Camp. coli, Cl. difficile, and Candida albicans). However, bacteriocin production has been widely studied due to the potential application of these molecules in current and potential applications in the food industry and in veterinary and pharmaceutical areas [73, 185-187].

Bacteriocins are ribosomally synthesized proteinaceous compounds with antibacterial activity against closely related 
microorganisms [188]. On the other hand, some bacteriocins, with a broad spectrum of activity (e.g., nisin and pediocin), have inhibitory activity against important spoilage organisms and food-borne pathogens, including Bacillus cereus, Cl. botulinum, Ent. faecalis, Staph. Aureus, and L. monocytogenes $[36,189]$. In general, bacteriocins are nontoxic, active in a wide $\mathrm{pH}$ range, and sensitive to gastric proteinases; most retain their properties after high heat treatment and are stable over several months, during frozen and refrigeration storage and after drying [67]. Different bacteriocins have been studied and characterized (Table 2), but only nisin from Lact. lactis strains and pediocins from Pediococcus acidilactici strains have been approved as biopreservatives in food systems [190].

However, the production cost of bacteriocin production is an important economic factor that determines the industrial application of these biomolecules. For this reason, the main factors that influence the synthesis of bacteriocins (e.g., culture conditions and media composition) must be studied in depth to generate the necessary knowledge to optimize the production of these antibacterial compounds [73, 75, 187, 191-193].

\subsection{Factors Influencing Bacteriocin Production}

2.1.1. Cultivation Method. Although in general, bacteriocins from lactococci and lactobacilli have been produced in batch cultures, increases in bacteriocin production have been obtained with the use of continuous and fed-batch fermentations. For example, continuous cultures with Lact. lactis subsp. lactis ATCC 11454 [194] and L. bavaricus MN [195] resulted, respectively, in an increase in the titres of nisin and bavaricin in comparison to the productions obtained in the batch cultures. On the other hand, different fed-batch fermentation methods have been successfully implemented to produce enhanced concentrations of nisin by different strains of Lact. lactis [75, 196-198] and amylovorin L471 by L. amylovorus DCE 471 [199].

2.1.2. Culture Media. Although De Vuyst [200] designed a culture medium containing at least 8 amino acids (considered essential for growth), 4 vitamins, a mixture of salts and sucrose for nisin production of by Lact. lactis NIZO 22186, bacteriocin production has been commonly carried out by using complex culture media (Table 3 ).

However, the use of these broths could be uneconomic for a high-scale production due to their high cost of these complex culture media. For this reason, the interest has been focused on the use of inexpensive culture media from food wastes including sugar molasses [201], cottonseed [202, 203], mussel processing wastes [75, 187, 192, 204], or whey (Table 4).

2.1.3. Effect of Culture $p H$. This is probably the most important variable influencing bacteriocin production [67]. However, the effect of the culture $\mathrm{pH}$ in growth and bacteriocin production depends on the culture media and the bacteriocin-producing strain $[67,73,187]$.
The culture $\mathrm{pH}$ determines the rate of nutrient intake by the cells and consequently, the growth of the bacteriocinproducing strains. Usually, nutrient consumption is optimal at $\mathrm{pH}$ values between 6.0 and 6.5 for lactococci and lactobacilli, but decreases rapidly at higher or lower values, probably caused by caused by a limitation of cytoplasmic processes including the acidification of the cytoplasm and the collapse of the proton motive force [191, 205-207]. On the other hand, the culture $\mathrm{pH}$ also produces a specific effect on bacteriocin production, which is dependent on the initial $\mathrm{pH}$ of the culture, the $\mathrm{pH}$ time-course, $\mathrm{pH}$ drop, and the final $\mathrm{pH}$ values reached in the fermentation $[65,66,74$, 196]. Thus, since the production of bacteriocins depends on both the growth and the evolution of the culture $\mathrm{pH}$, these antimicrobial compounds have been classified as $\mathrm{pH}$ dependent primary metabolites $[74,196]$.

2.1.4. Effect of the Carbon Source. Although L. amylovorus can grow on polysaccharides [208], it is clear that the best carbon source for bacteriocin production must be a simple sugar, preferably glucose [3, 191]. Thus, some researchers have made comparative studies on the influence of different carbon sources on the production of bacteriocins. The results obtained showed that the higher bacteriocin titers of nisin A [209], nisin Z [210] and lactocin 705 [63] were obtained when glucose was used as a carbon source.

2.1.5. Effect of the Nitrogen Source. Protein hydrolysates of high quality (casein hydrolyzate, tryptones, and peptones), yeast extract, and meat extract have proved to be the best nitrogen sources for production of lactocin D [211], lactocin 705 [63], and nisin [203, 212-214]. However, this approach could be uneconomic for a high-scale bacteriocin production due to the high cost of the complex nitrogen sources in comparison with the low cost of the wastes from the food industry $[190,191]$. For this reason, the studies have been focused on finding other nitrogen sources of low cost for bacteriocin production. In this way, high yields of nisin have been obtained with the use of inexpensive low metabolizable nitrogen sources such as cotton seed meal, blood meal, and fish meal [213]. The low release effects of these nitrogen sources probably prevent the manifestation of the regulatory actions that the high concentrations of the nitrogen source produce on bacteriocin production [213].

The inducing effect of some amino acids in bacteriocin production was studied by De Vuyst [200], who demonstrated that cysteine, serine, and threonine (at a concentration of $0.1 \%$ ) stimulated nisin production, without affecting biomass production. However, higher concentrations of these nitrogen sources caused a drastic decrease in nisin production.

Baranova and Egorov [212] studied the influence of organic ammonium salts from succinic, citric, acetic, and oxalic acid and inorganic salts $\left(\mathrm{NH}_{4} \mathrm{Cl},\left(\mathrm{NH}_{4}\right)_{2} \mathrm{SO}_{4}\right.$, $\mathrm{NH}_{4} \mathrm{NO}_{3}$ ) on nisin production. The results obtained showed that the latter nitrogen sources did not affect the growth of Lact. lactis subsp. lactis MSU and nisin production. However, salts from organic acids stimulated the accumulation of 
TABLE 2: Some characteristics of bacteriocins produced by some Lactococci and Lactobacilli.

\begin{tabular}{|c|c|c|c|c|c|c|}
\hline Bacteriocin & Producer & $\begin{array}{l}\text { Molecular } \\
\text { weight }(\mathrm{Da})\end{array}$ & Stability & Sensibility & $\begin{array}{c}\text { Antibacterial activity } \\
\text { against }\end{array}$ & References \\
\hline Lacticin 3147 & $\begin{array}{l}\text { Lact. lactis } \\
\text { DPC3147 }\end{array}$ & - & $\begin{array}{l}100^{\circ} \mathrm{C} / 10 \text { min at } \\
\mathrm{pH}<5.0 ; \text { catalase }\end{array}$ & $\begin{array}{l}\text { Proteinase K, trypsin, } \\
\text { pronase E, } \\
\text { chymotrypsin, pepsin }\end{array}$ & $\begin{array}{l}\text { Ac. aceti, bacilli, clostridia, } \\
\text { enterococci, lactobacilli, } \\
\text { lactococci, leuconostocs, } \\
\text { listeria, pediococci, } \\
\text { staphylococci, streptococci }\end{array}$ & {$[26]$} \\
\hline Lactococin I & $\begin{array}{c}\text { Lact. lactis } \\
\text { subsp. cremoris } \\
\text { AC1 }\end{array}$ & 6,000 & $\begin{array}{l}100^{\circ} \mathrm{C} / 30 \mathrm{~min} \\
\mathrm{pH}=4.5-7.0\end{array}$ & Proteolytic enzymes & Lactococci, clostridia & {$[27]$} \\
\hline $\begin{array}{l}\text { Lactoestrepcins } \\
1,2,3 \text { and } 4\end{array}$ & $\begin{array}{l}\text { Non-nisin } \\
\text { producers } \\
\text { strains of Lact. } \\
\text { lactis subsp. } \\
\text { cremoris, lactis } \\
\text { and diacetylactis }\end{array}$ & $>10,000$ & $\begin{array}{l}121^{\circ} \mathrm{C} / 10 \mathrm{~min} \\
\mathrm{pH}<5.0\end{array}$ & $\begin{array}{l}\text { Trypsin, pronase, } \\
\text { chymotrypsin, lipases; } \\
\text { pH > } 7.0\end{array}$ & $\begin{array}{c}\text { Lactococci, streptococci, Bac. } \\
\text { cereus, L. helveticus, } \\
\text { L. citrovorum, } \\
\text { L. paracitrovorum }\end{array}$ & {$[28,29]$} \\
\hline Lacticin 481 & $\begin{array}{l}\text { Lact. lactis } \\
\text { subsp. lactis } \\
\text { CNRZ } 481\end{array}$ & $\begin{array}{c}\text { Between } \\
1,300 \text { and } \\
2,700\end{array}$ & $100^{\circ} \mathrm{C} / 1 \mathrm{~h}$ & Proteolytic enzymes & $\begin{array}{c}\text { Lactococci, lactobacilli, } \\
\text { leuconostocs, } \\
\text { Cl. tyrobutyricum }\end{array}$ & {$[30,31]$} \\
\hline Nisin A & $\begin{array}{l}\text { Lact. lactis } \\
\text { subsp. lactis } \\
\text { ATTC } 11454\end{array}$ & 3,354 & $\begin{array}{l}121^{\circ} \mathrm{C} / 15 \mathrm{~min}, \\
\text { at } \mathrm{pH}=2.0 ; \\
100^{\circ} \mathrm{C} / 10 \mathrm{~min} ; \\
\text { pronase, trypsin, } \\
\text { erepsin, elastase, } \\
\text { carboxypeptidase and } \\
\text { pepsin at acidic } \mathrm{pH}\end{array}$ & $\begin{array}{l}\text { Chymotrypsin, ficin, } \\
\text { papain }\end{array}$ & $\begin{array}{c}\text { Lactococci, bacilli, } \\
\text { clostridia, Staph. aureus, } \\
\text { micrococci } \\
\text { L. monocytogenes, } \\
\text { L. innocua, carnobacteria }\end{array}$ & {$[32-35]$} \\
\hline Nisin Z & $\begin{array}{l}\text { Lact. lactis } \\
\text { subsp. lactis } \\
\text { NIZO } 22186\end{array}$ & 3,354 & $\begin{array}{l}121^{\circ} \mathrm{C} / 15 \mathrm{~min}, \\
\text { at } \mathrm{pH}=2.0 ; \\
100^{\circ} \mathrm{C} / 10 \mathrm{~min} ; \\
\text { pronase, trypsin, } \\
\text { erepsin, elastase, } \\
\text { carboxypeptidase and } \\
\text { pepsin at acidic } \mathrm{pH}\end{array}$ & $\begin{array}{l}\text { Chymotrypsin, ficin, } \\
\text { papain }\end{array}$ & $\begin{array}{c}\text { Lactococci, Bacilli, } \\
\text { Clostridia, Staph. aureus, } \\
\text { Micrococci } \\
\text { L. monocytogenes }\end{array}$ & {$[35]$} \\
\hline Lactacin B & $\begin{array}{l}\text { L. acidophilus } \\
\text { N2 }\end{array}$ & 6,300 & $\begin{array}{l}100^{\circ} \mathrm{C} / 60 \mathrm{~min} \\
121^{\circ} \mathrm{C} / 3 \mathrm{~min} \\
-20^{\circ} \mathrm{C} \\
\text { catalase }\end{array}$ & $\begin{array}{l}\text { Proteinase K, } \\
\text { pronase }\end{array}$ & $\begin{array}{c}\text { Lactobacilli, Proteus, } \\
\text { Salmonella, } \\
\text { staphylococi, streptococci, } \\
\text { bacilli }\end{array}$ & {$[36]$} \\
\hline Acidocin J1132 & $\begin{array}{l}\text { L. acidophilus } \\
\text { JCM } 1132\end{array}$ & $\begin{array}{l}\alpha: 6,220 \\
\beta: 6,280\end{array}$ & $100^{\circ} \mathrm{C} / 30 \mathrm{~min}$; catalase & $\begin{array}{l}\text { Pronase, proteinase } \mathrm{K}, \\
\text { trypsin, pepsin }\end{array}$ & $\begin{array}{l}\text { L. acidophilus, L. casei, } \\
\text { L. plantarum }\end{array}$ & [37] \\
\hline Acidocin 8912 & $\begin{array}{l}\text { L. acidophilus } \\
\text { TK } 8912\end{array}$ & 5,200 & $120^{\circ} \mathrm{C} / 20 \mathrm{~min}$ & $\begin{array}{l}\text { Proteinase K, } \\
\text { pepsin, trypsin, } \\
\text { chymotrypsin }\end{array}$ & $\begin{array}{c}\text { L. acidophilus, } L . \\
\text { plantarum, L. casei, Lact. } \\
\text { lactis }\end{array}$ & {$[38]$} \\
\hline BLIS LF221 & $\begin{array}{l}\text { L. acidophilus } \\
\text { LF221 }\end{array}$ & - & $\begin{array}{l}100^{\circ} \mathrm{C} / 5 \mathrm{~min} \\
\mathrm{pH}=2.0-9.0\end{array}$ & $\begin{array}{l}\text { Trypsin, pepsin, } \\
\text { proteinase } \mathrm{K} \text { and } \\
\text { pronase; } \mathrm{pH}=10.0\end{array}$ & $\begin{array}{c}\text { L. helveticus, Bac. cereus, } \\
\text { Clostridium sp., L. innocua, } \\
\text { Staph. aureus. }\end{array}$ & [39] \\
\hline Brevicin B37 & L. brevis 37 & $>10,000$ & $\begin{array}{l}121^{\circ} \mathrm{C} / 60 \mathrm{~min} \\
\mathrm{pH}=2.0-10.0\end{array}$ & $\begin{array}{l}\mathrm{pH}>12.0 \text { a } 25^{\circ} \mathrm{C} ; \\
\text { pronase } \mathrm{E}, \\
\text { trypsin }\end{array}$ & $\begin{array}{l}\text { Pediococci, leuconostocs, } \\
\text { lactobacilli, N. coralina }\end{array}$ & {$[40]$} \\
\hline Bulgarican & $\begin{array}{l}\text { L. bulgaricus } \\
\text { DDS14 }\end{array}$ & - & $\begin{array}{l}121^{\circ} \mathrm{C} / 60 \mathrm{~min} \\
\mathrm{pH}<6.0\end{array}$ & $\mathrm{pH}>6.0$ & Staph. aureus & [41] \\
\hline BLIS & $\begin{array}{l}\text { L. bulgaricus } \\
7994 \\
\end{array}$ & 0,700 & $\begin{array}{l}100^{\circ} \mathrm{C} / 1 \mathrm{~h} ; \\
6^{\circ} \mathrm{C} / 18 \text { days }\end{array}$ & $\begin{array}{l}121^{\circ} \mathrm{C} / 15 \mathrm{~min} \\
\mathrm{pH}=5.0-12.0\end{array}$ & P. fragi, Staph. aureus & {$[42]$} \\
\hline Curvacin A & $\begin{array}{l}\text { L. curvatus } \\
\text { LTH } 1174\end{array}$ & $3,000-5,000$ & $\begin{array}{l}100^{\circ} \mathrm{C} / 3 \mathrm{~min} \text {; } \\
\text { pepsin }\end{array}$ & $\begin{array}{l}\text { Proteinase K, } \\
\text { trypsin }\end{array}$ & $\begin{array}{l}\text { Lactobacilli, leuconostocs, } \\
\text { carnobacteria, Listeria sp., } \\
\text { micrococci, Staphhylococci }\end{array}$ & {$[43]$} \\
\hline
\end{tabular}


TABle 2: Continued.

\begin{tabular}{|c|c|c|c|c|c|c|}
\hline Bacteriocin & Producer & $\begin{array}{c}\text { Molecular } \\
\text { weight }(\mathrm{Da})\end{array}$ & Stability & Sensibility & $\begin{array}{c}\text { Antibacterial activity } \\
\text { against }\end{array}$ & References \\
\hline BLIS IFPL105 & $\begin{array}{l}\text { L. curvatus } \\
\text { IFPL105 }\end{array}$ & - & $\begin{array}{l}121^{\circ} \mathrm{C} / 15 \mathrm{~min} \\
\mathrm{pH}=5.0-7.0 \\
\text { trypsin, pepsin }\end{array}$ & $\begin{array}{l}121^{\circ} \mathrm{C} / 30 \mathrm{~min}, \\
\text { chymotrypsin, } \\
\text { proteinase } \mathrm{K}, \\
\text { pancreatin }\end{array}$ & $\begin{array}{l}\text { Lactococci, Lactobacilli, } \\
\text { Clostridia, Listeria, } \\
\text { B. subtilis, S. thermophilus, }\end{array}$ & {$[44]$} \\
\hline Lacticin B & $\begin{array}{l}\text { L. delbrueckii } \\
\text { subsp. lactis } \\
\text { JCM } 1248\end{array}$ & - & - & $\begin{array}{l}60^{\circ} \mathrm{C} / 10 \mathrm{~min} \text {; } \\
\text { proteolytic enzymes }\end{array}$ & $\begin{array}{l}\text { L. delbrueckii subsp. lactis, } \\
\text { L. delbrueckii subsp. } \\
\text { delbrueckii }\end{array}$ & {$[45]$} \\
\hline Fermenticin & $\begin{array}{l}\text { L. fermentum } \\
466\end{array}$ & - & $\begin{array}{l}96^{\circ} \mathrm{C} / 30 \mathrm{~min} ; \\
\mathrm{pH}=1.0-14.0 \\
\text { lysozyme }\end{array}$ & $\begin{array}{l}\text { Trypsin, } \\
\text { pepsin }\end{array}$ & Lactobacilli & {$[46]$} \\
\hline Fermenticin B & $\begin{array}{l}\text { L. fermentum } \\
\text { CCRC } 14018\end{array}$ & $1,000-3,000$ & $\begin{array}{l}100^{\circ} \mathrm{C} / 30 \mathrm{~min} \\
\mathrm{pH}=3.0-8.0 \text { during } \\
36 \mathrm{~h} \text { at } 4^{\circ} \mathrm{C}\end{array}$ & $\begin{array}{l}\mathrm{pH}>8.0 ; \\
\text { proteinase } \mathrm{K}, \\
\text { chymotrypsin, } \\
\text { amyloglucosidase at } \\
30^{\circ} \mathrm{C} / 1 \mathrm{~h}\end{array}$ & $\begin{array}{l}\text { L. plantarum subsp., } \\
\text { L. pentosus, L. brevis, } \\
\text { L. delbrueckii subsp. } \\
\text { bulgaricus, L. helveticus } \\
\text { subsp., } \\
\text { M. luteus } \\
\end{array}$ & {$[47]$} \\
\hline Gassericin A & $\begin{array}{l}\text { L. gasseri } \\
\text { LA39 }\end{array}$ & 6,300 & $120^{\circ} \mathrm{C} / 20 \mathrm{~min}$ & Trypsin & Lactobacilli & {$[48]$} \\
\hline Helveticin J & $\begin{array}{c}\text { L. helveticus } \\
481\end{array}$ & 37,000 & Lipase, lisozime & $\begin{array}{l}\text { Heat; } \\
\text { ficin, pronase, } \\
\text { trypsin, pepsin, } \\
\text { proteinase K, subtilisin }\end{array}$ & $\begin{array}{c}\text { L. bulgaricus, Lact. lactis, } \\
\text { L. helveticus }\end{array}$ & {$[49]$} \\
\hline $\begin{array}{l}\text { Helveticin } \\
\text { V-1829 }\end{array}$ & $\begin{array}{l}\text { L. helveticus } \\
\text { V-1829 }\end{array}$ & $>10,000$ & $\begin{array}{l}45^{\circ} \mathrm{C} / 120 \mathrm{~min} \\
\mathrm{pH}=2.5-6.5\end{array}$ & $\begin{array}{l}50^{\circ} \mathrm{C} / 30 \mathrm{~min} ; \\
\mathrm{pH}>7.0 ; \\
\text { proteinase } \mathrm{K}, \text { ficin, } \\
\text { trypsin, } \\
\text { pronase }\end{array}$ & Lactobacilli & {$[50]$} \\
\hline Lactacin F & $\begin{array}{l}\text { L. johnsonii } \\
\text { VPI11088 }\end{array}$ & 2,500 & $121^{\circ} \mathrm{C} / 15 \mathrm{~min}$ & $\begin{array}{l}\text { Proteinase K, } \\
\text { trypsin, ficin, } \\
\text { subtilisin }\end{array}$ & Lactobacilli, Ent. faecalis & {$[51]$} \\
\hline $\begin{array}{l}\text { Plantaricins A, } \\
\text { EF, JK and N }\end{array}$ & $\begin{array}{l}\text { L. plantarum } \\
\text { C-11 }\end{array}$ & $>8,000$ & $\begin{array}{l}100^{\circ} \mathrm{C} / 30 \mathrm{~min} \\
\mathrm{pH}=4.0-6.5\end{array}$ & Proteolytic enzymes & $\begin{array}{c}\text { Lactobacilli, carnobacteria } \\
\text { pediococci, leuconostocs, } \\
\text { lactococci, enterococci }\end{array}$ & {$[52,53]$} \\
\hline Plantaricin $\mathrm{C}$ & $\begin{array}{l}\text { L. plantarum } \\
\text { LL441 }\end{array}$ & 3,500 & $\begin{array}{l}4^{\circ} \mathrm{C},-20^{\circ} \mathrm{C} ; \\
100^{\circ} \mathrm{C} / 60 \mathrm{~min}, \\
121^{\circ} \mathrm{C} / 10 \mathrm{~min} ; \\
\mathrm{pH}<7.0 ; \\
\text { pepsin, proteinase } \mathrm{K} \text {, } \\
\text { amylase, lipase }\end{array}$ & $\begin{array}{l}\mathrm{pH}>7.0 ; \\
\text { pronase, trypsin, } \\
\text { chymotrypsin }\end{array}$ & $\begin{array}{c}\text { Lactobacilli, pediococci, } \\
\text { leuconostocs, } \\
\text { Prop. acidopropionici, } \\
\text { Lact. cremoris, S. } \\
\text { thermophilus, } \\
\text { Ent. faecalis, S. carnosus, } \\
\text { Bac. subtilis, Cl. sporogenes, } \\
\text { Cl. tyrobutyricum }\end{array}$ & {$[54]$} \\
\hline Plantaricin S & $\begin{array}{l}\text { L. plantarum } \\
\text { LPC010 }\end{array}$ & 2,500 & $\begin{array}{l}100^{\circ} \mathrm{C} / 60 \mathrm{~min} \\
\mathrm{pH}=3.0-7.0\end{array}$ & - & $\begin{array}{l}\text { Leuconostocs, clostridia, } \\
\text { lactobacilli, enterococci, } \\
\text { pediococci, lactococci, } \\
\text { streptococci, } \\
\text { Propionibacterium }\end{array}$ & {$[55]$} \\
\hline Plantaricin $\mathrm{T}$ & $\begin{array}{l}\text { L. plantarum } \\
\text { LPC010 }\end{array}$ & 2,000 & $\begin{array}{l}100^{\circ} \mathrm{C} / 60 \mathrm{~min} \\
\mathrm{pH}=3.0-7.0 \\
\text { amylase, lipase }\end{array}$ & Proteolytic enzymes & $\begin{array}{l}\text { Leuconostocs, clostridia, } \\
\text { lactobacilli, enterococci, } \\
\text { pediococci, lactococci, } \\
\text { streptococci, micrococci, } \\
\text { Propionibacterium }\end{array}$ & {$[55]$} \\
\hline Reutericin 6 & L. reuteri LA6 & 200,000 & $100^{\circ} \mathrm{C} / 60 \mathrm{~min}$ & $\begin{array}{l}121^{\circ} \mathrm{C} / 20 \mathrm{~min}, \\
\text { proteolytic enzymes }\end{array}$ & $\begin{array}{c}\text { L. acidophilus, L. delbrueckii } \\
\text { subsp. bulgaricus } \\
\text { and subsp. lactis }\end{array}$ & {$[56]$} \\
\hline
\end{tabular}


TABle 2: Continued.

\begin{tabular}{|c|c|c|c|c|c|c|}
\hline Bacteriocin & Producer & $\begin{array}{c}\text { Molecular } \\
\text { weight (Da) }\end{array}$ & Stability & Sensibility & $\begin{array}{c}\text { Antibacterial activity } \\
\text { against }\end{array}$ & References \\
\hline Sakacin A & L. sake 706 & 4,380 & $\begin{array}{l}100^{\circ} \mathrm{C} / 20 \mathrm{~min} \\
-20^{\circ} \mathrm{C}\end{array}$ & Trypsin, pepsin & $\begin{array}{c}\text { Leuconostocs, lactobacilli, } \\
\text { enterococci, } \\
\text { Lact. lactis subsp. cremoris, } \\
\text { L. monocytogenes, } \\
\text { A. hydrophila, } \\
\text { Staph. aureus }\end{array}$ & {$[57]$} \\
\hline Sakacin B & L. sake 251 & 6,300 & $\begin{array}{l}100^{\circ} \mathrm{C} / 20 \mathrm{~min} \\
\mathrm{pH}=2.0-9.0\end{array}$ & $\begin{array}{l}\text { Protease XV, } \\
\text { bromelain }\end{array}$ & $\begin{array}{c}\text { L. plantarum, L. curvatus, } \\
\text { L. sake } \\
\text { L. minor, L. halotolerans, } \\
\text { L. viridescens, Leuc. } \\
\text { mesenteroides } \\
\text { Streptococcus sp. }\end{array}$ & {$[58]$} \\
\hline Sakacin M & L. sake 148 & 4,640 & $\begin{array}{l}80^{\circ} \mathrm{C} / 60 \mathrm{~min} \\
150^{\circ} \mathrm{C} / 9 \mathrm{~min}\end{array}$ & $\begin{array}{l}\text { Pepsin, trypsin, } \\
\text { papain, proteases II } \\
\text { and XIV }\end{array}$ & $\begin{array}{c}\text { Lactobacilli, leuconostocs, } \\
\text { carnobacteria, } \\
\text { L. monocytogenes, } \\
\text { Staph. aureus }\end{array}$ & [59] \\
\hline Sakacin P & L. sake LTH 673 & $3,000-5,000$ & $\begin{array}{l}100^{\circ} \mathrm{C} / 30 \mathrm{~min} \text {; } \\
\text { pepsin }\end{array}$ & Proteinase K, trypsin & $\begin{array}{l}\text { Lactobacilli, leuconostocs, } \\
\text { carnobacteria, enterococci, } \\
\text { Br. thermosphacta, listeria }\end{array}$ & {$[43]$} \\
\hline Salivacin 140 & $\begin{array}{c}\text { L. salivarus } \\
\text { subsp. salicinius } \\
\text { T140 }\end{array}$ & - & Catalase & Pronase E & $\begin{array}{c}\text { L. monocytogenes, } \\
\text { S. mutans Staph. } \\
\text { aureus, lactobacilli, Act. } \\
\text { viscosus, Y. enterocolitica } \\
\text { Prop. acnes }\end{array}$ & {$[60]$} \\
\hline
\end{tabular}

TABLE 3: Some complex culture media commonly used for bacteriocin production by Lactococci and Lactobacilli.

\begin{tabular}{|c|c|c|c|}
\hline Bacteriocin & Producing strain & Culture media & Reference \\
\hline Amilovorin L471 & L. amylovorus DCE 471 & MRS & {$[61]$} \\
\hline Brevicin & L. brevis VB286 & MRS & {$[62]$} \\
\hline Lactacin B & L. acidophilus N2 & MRS & {$[36]$} \\
\hline Lactocin 705 & L. casei CRL 705 & MRS, Elliker, BHI, M17 & {$[63]$} \\
\hline Lactococin $\mathrm{G}$ & Lact. lactis LMG 2081 & M17 & {$[64]$} \\
\hline \multirow{3}{*}{ Nisin } & Lact. lactis ATCC 11454 & Buffered TGE & {$[65,66]$} \\
\hline & Lact. lactis subsp. lactis & M17 & {$[62]$} \\
\hline & Lact. lactis subsp. lactis CECT 539 & MRS & {$[67]$} \\
\hline Plantaricin A & L. plantarum $\mathrm{C}-11$ & MRS & {$[52]$} \\
\hline Plantaricin $\mathrm{C}$ & L. plantarum LL441 & MRS & {$[54]$} \\
\hline Sakacin A & L. sake $\mathrm{LB} 706$ & MRS, TGE & {$[65,66]$} \\
\hline Salivaricin 140 & L. salivarus subsp. salicinius $\mathrm{T} 140$ & MRS & {$[60]$} \\
\hline
\end{tabular}

TABLE 4: Some examples of bacteriocins produced by Lactococci and Lactobacilli in whey-based media.

\begin{tabular}{|c|c|c|c|c|}
\hline Bacteriocin & Producing strain & Fermentation mode & Culture medium & Reference \\
\hline Plantaricin UG1 & L. plantarum UG1 & Batch & WP & {$[68]$} \\
\hline Lacticin 3147 & Lact. lactis DPC3147 & Continuous & Demineralized whey protein fermentation liquor & {$[69]$} \\
\hline \multirow{2}{*}{ Nisin Z } & \multirow{2}{*}{ Lact. lactis UL719 } & Continuous & $\mathrm{WP}+0.2 \mathrm{M} \mathrm{KCl}$ & {$[70]$} \\
\hline & & Batch & $\mathrm{WP}+1 \%(\mathrm{w} / \mathrm{v}) \mathrm{YE}$ and $0.1 \%(\mathrm{w} / \mathrm{v})$ Tween 80 & {$[71]$} \\
\hline $\begin{array}{l}\text { Nisin } \mathrm{Z} / \text { pediocin } \\
\text { mixture }\end{array}$ & $\begin{array}{l}\text { Lact. lactis UL719 and } \\
\text { Ped. acidilactici UL5 }\end{array}$ & Batch & $\mathrm{WP}+2 \%(\mathrm{w} / \mathrm{v}) \mathrm{YE}$ and $0.1 \%(\mathrm{v} / \mathrm{v})$ Tween 80 & {$[72]$} \\
\hline \multirow{2}{*}{ Nisin } & \multirow{2}{*}{$\begin{array}{l}\text { Lact. lactis subsp. } \\
\text { lactis CECT539 }\end{array}$} & Batch & DW & {$[73,74]$} \\
\hline & & Re-alkalized fed-batch & DW & {$[75]$} \\
\hline
\end{tabular}

WP: whey permeate; DW: deproteinized whey; YE: yeast extract. 
biomass and bacteriocin. These authors justify this behavior, suggesting that ammonium forms of nitrogen are used by the Lact. lactis, and that the positive effect that the organic ammonium salts produces on nisin production could be related to the presence of organic acids.

2.1.6. Effect of the Phosphorous Source. Although the phosphorous source is usually supplied as soluble salts, other ingredients (tryptone and yeast extract) frequently used in the media contain small amounts of this substrate [215].

Baranova and Egorov [209] obtained the highest productions of biomass and nisin by Lact. lactis subsp. lactis MSU when the culture medium was supplemented with $\mathrm{KH}_{2} \mathrm{PO}_{4}$ at a concentration of $30 \mathrm{~g} / \mathrm{L}$. De Vuyst and Vandamme [203] also selected this salt as the best phosphorus source for nisin production by Lact. lactis subsp. lactis NIZO 22186. However, when the initial concentration of $\mathrm{KH}_{2} \mathrm{PO}_{4}$ was greater than $50 \mathrm{~g} / \mathrm{L}$, the nisin production decreased dramatically.

On the contrary, this salt did not produce a relevant positive effect on both nisin and biomass production by Lact. lactis subsp. lactis CECT 538 in culture media prepared with whey [73] or mussel processing wastes [187].

\section{Production and Modelling of Highly Concentrated Cultures of Lactobacilli and Lactococci Strains Containing Higher Concentrations of Viable Cells and Bacteriocins}

As commented above, the probiotic lactobacilli and lactococci cells and their bacteriocins have a potential application in the food, veterinary, and pharmaceutical industries. However, for their industrial applications, the live cells and their antimicrobial products must be produced at high concentrations in low-cost culture media based prepared with wastes or by-products from the food industry. For this purpose, it is necessary to design and optimize a suitable fermentation method with an adequate control-system [76, 199, 216, 217].

In this way, Callewaert and De Vuyst [199] optimized the production of amylovorin L471 by L. amylovorus DCE 471 in MRS broth by using a fed-batch fermentation technique based on the continuous supply of fresh medium. In addition, the productions of biomass and bacteriocin by Lact. lactis subsp. lactis CECT 539 [75] and L. casei subsp. casei CECT 4043 [191] were improved by using a fed-batch fermentation technique based on successive realkalizations of the culture medium [196].

Due to the lack of accurate models describing cell growth and product formation in this type of cultures, different mathematical models were developed for describing the fedbatch productions of biomass and bacteriocins by the strains DCE 471 [199], CECT 539 [217], and CECT 4043 [76].

Thus, the models developed to describe the amylovorin L471 production system were [199].

For biomass production:

$$
\frac{d V X}{d t}=\mu \cdot X \cdot V-F_{\text {out }} \cdot X
$$

with

$$
\mu=\mu_{\max } \cdot \frac{S}{S+K_{S}+S^{2} / K_{i S}} \cdot \frac{N}{N+K_{N}} \cdot \frac{K_{i L}}{L+K_{i L}},
$$

where $V$ is the volume of the fermentation medium $(L)$ and $F_{\text {out }}$ is the outflow $(\mathrm{L} / \mathrm{h}) . X$ is the biomass concentration ( $\mathrm{g}$ of cell dry mass (CDM)/L), $\mu$ and $\mu_{\max }$ are the specific growth rate and the maximal specific growth rate, respectively $\left(\mathrm{h}^{-1}\right)$, $S$ is the concentration of the energy source $(\mathrm{g} / \mathrm{L}), N$ is the concentration of the CNS $(\mathrm{g} / \mathrm{L})$, and $K_{S}$ and $K_{N}$ are the corresponding Monod constants for glucose $(\mathrm{g} / \mathrm{L})$ and CNS $(\mathrm{g} / \mathrm{L})$, respectively; $L$ is the lactic acid concentration $(\mathrm{g} / \mathrm{L})$ and $K_{i s}$ and $K_{i L}$ are the inhibition constants for glucose $(\mathrm{g} / \mathrm{L})$ and lactic acid (g/L), respectively [199]. According to these authors, the CNS (complex nitrogen source) contained $(\mathrm{g} / \mathrm{g})$ : Lab Lemco powder (Oxoid), 0.36; yeast extract (Merck), 0.18; bacteriological peptone (Oxoid), 0.46.

For bacteriocin production, the model developed was [199]:

$$
\begin{aligned}
\frac{d V B}{d t}= & k_{B} \cdot \frac{K_{i B N}}{N+K_{i B N}} \mu \cdot X \cdot V-k_{B}^{\prime} \cdot \frac{K_{i B N}^{\prime}}{N+K_{i B N}^{\prime}} \\
& \cdot \frac{L}{L+K_{B L}^{\prime}} B \cdot V-F_{\text {out }} \cdot B,
\end{aligned}
$$

where $B$ is the bacteriocin titer (in mega activity units (MAU) per liter), $k_{B}$ is the specific bacteriocin production (MAU/g CDM), $K_{i B N}$ is the CNS inhibition constant for bacteriocin production $(\mathrm{g} / \mathrm{L}), k_{B}^{\prime}$ is the specific bacteriocin adsorption rate $\left(\mathrm{h}^{-1}\right), K_{i B N}^{\prime}$ is the CNS inhibition constant for bacteriocin adsorption $(\mathrm{g} / \mathrm{L})$, and $K_{B L}^{\prime}$ is the lactic acid constant for bacteriocin adsorption (g/L) [199].

On the other hand, in the realkalized fed-batch fermentations with the strains CECT 539 and CECT 4043 in whey, the cultures were periodically fed with concentrated substrates containing lactose and/or glucose to replenish the sugars consumed by the growing cultures. For this reason, Guerra et al. [76, 217] considered that the nitrogen source was the limiting nutrient for the growth of both LAB. In addition, the authors observed two growth phases (diauxic growth), which paralleled with two nitrogen consumption phases. Taking into account these considerations, the researchers developed the following mathematical models.

For biomass production:

$$
\frac{d X}{d t}=\left(\mu-k_{d}\right) \cdot X
$$

with

$$
\mu=\left(\frac{\mu_{\max 1} \cdot\left(N-N_{\min 1}\right)}{K_{N 1}+\left(N-N_{\min 1}\right)}+\frac{\mu_{\max 2} \cdot\left(N-N_{\min 2}\right)}{K_{N 2}+\left(N-N_{\min 2}\right)}\right) \cdot \gamma_{i},
$$

being $\gamma_{i}$

$$
\begin{aligned}
& \gamma_{i}=\gamma \mathrm{LA} \cdot \gamma \mathrm{AA} \cdot \gamma \mathrm{Et} \cdot \gamma \mathrm{B}=\left(\frac{K_{\mathrm{LA}}}{\mathrm{LA}+K_{\mathrm{LA}}}\right) \cdot\left(\frac{K_{\mathrm{AA}}}{\mathrm{AA}+K_{\mathrm{AA}}}\right) \\
& \cdot\left(\frac{K_{\mathrm{Et}}}{\mathrm{Et}+K_{\mathrm{Et}}}\right) \cdot\left(\frac{K_{\mathrm{B}}}{\mathrm{B}+K_{\mathrm{B}}}\right)
\end{aligned}
$$


where $X$ is the biomass concentration $(\mathrm{gCDM} / \mathrm{L}), t$ is the time $(\mathrm{h})$ and $k_{d}$ is the cell death rate $\left(\mathrm{h}^{-1}\right) . N$ is the nitrogen concentration $(\mathrm{g} / \mathrm{L}), \mu_{\max 1}$ and $\mu_{\max 2}$ are the specific growth rates $\left(\mathrm{h}^{-1}\right)$ of the exponential growth phases 1 and 2, respectively. $K_{N 1}$ and $K_{N 2}$ are the nitrogen affinity constants $(\mathrm{g} / \mathrm{L})$ in each phase of nitrogen consumption. $N_{\min 1}$ and $N_{\min 2}$ are the minimum nitrogen concentrations $(\mathrm{g} / \mathrm{L})$ that support the biomass production in each growth phase. $\gamma \mathrm{LA}, \gamma \mathrm{AA}, \gamma \mathrm{Et}$, and $\gamma \mathrm{B}$ are the individual inhibition functions for lactic acid, acetic acid, ethanol, and butane-2,3diol inhibition, respectively. $K_{\mathrm{LA}}, K_{\mathrm{AA}}, K_{\mathrm{Et}}$, and $K_{\mathrm{B}}$ are the inhibition constants $(\mathrm{g} / \mathrm{L})$ for lactic acid, acetic acid, ethanol, and butane-2,3-diol, respectively. LA, AA, Et, and B are the total concentrations $(\mathrm{g} / \mathrm{L})$ of lactic acid, acetic acid, ethanol, and butane-2,3-diol over the time, respectively.

Since bacteriocin production depends on the growth and culture $\mathrm{pH}$, and the effect of the latter variable depends on the bacteriocin-producing strain, the Luedeking and Piret model [218] was modified to describe bacteriocin or antibacterial activity production as follows:

$$
\frac{d B}{d t}=(\alpha \cdot \mu \cdot X+\beta \cdot X) \cdot\left(1-\kappa \cdot\left|\frac{\mathrm{pH} t-\mathrm{pHop}}{\mathrm{pHop}}\right|\right)
$$

for nisin production [217] and

$$
\frac{d \mathrm{AbA}}{d t}=(\alpha \cdot \mu \cdot X+\beta \cdot X) \cdot\left(1+e^{-\kappa_{1} \cdot(r \mathrm{pH} \max -r \mathrm{pH})}\right)
$$

for antibacterial activity of strain CECT 4043 [76], where $B$ is the bacteriocin concentration $(\mathrm{BU} / \mathrm{mL}, 1 \mathrm{BU}$ corresponds to 20 International Units), $\alpha$ is a growth-associated constant for bacteriocin production (BU/mg), which corresponds to the yield product on biomass formed $\left(Y_{P / X}\right)$ for growthassociated metabolites, $\beta$ is the non-growth-associated constant $\left(\mathrm{BU} \cdot \mathrm{mg}^{-1} \cdot \mathrm{h}^{-1}\right), \kappa$ is a constant of proportionality, $\mathrm{pHop}$ is the optimum final $\mathrm{pH}$, from which bacteriocin production stopped, and $\mathrm{pH} t$ is the $\mathrm{pH}$ value in each sampling time [217].

$\mathrm{AbA}$ is the antibacterial activity concentrations $(\mathrm{AU} / \mathrm{mL})$, $\kappa_{1}$ is a constant of proportionality $(\mathrm{h}), r \mathrm{pH}$ and $r \mathrm{pHmax}$ are, respectively, the $\mathrm{pH}$ drop and the maximum $\mathrm{pH}$ drop $\left(\mathrm{h}^{-1}\right)$ for high AbA production [76].

According to the results obtained by both research groups $[76,199,217]$, excellent agreements were obtained between the experimental data of biomass and bacteriocin production and the predictions of the models developed by each research group. This indicates that the models proposed could be used to monitor and control the growth and bacteriocin production in these types of cultures [76, 217].

3.1. Mass Balance Equations. Other important aspect that must be considered for optimizing the production of highly concentrated probiotic cultures is the development of a suitable nutrient feeding strategy, in order to avoid both overfeeding and underfeeding of nutrients, which are detrimental to biomass and product synthesis [193]. For this purpose, development of the corresponding mass balance equations is necessary to calculate the adequate volumes of feeding substrates that must be added to the growing culture in order to avoid the manifestation of growth inhibition phenomena such as substrate inhibition [219] or nutrient depletion [220]. This also allows a better analysis of the evolution of the concentrations of nutrients and products in the fermentation process. With this procedure, the fermentation yields and efficiencies could be correctly calculated and consequently, the fermentation process could be more easily interpreted.

For example, Guerra et al. [76] formulated mass balance equations in two re-alkalized fed-batch cultures to calculate the volumes of feeding substrates, the concentrations of nutrients (lactose, glucose, proteins, nitrogen and phosphorous) added to the fermentation medium, as well as the concentrations of biomass and products during the fermentation process. The two fermentations were carried out at $30^{\circ} \mathrm{C} / 200 \mathrm{rpm}$ in a $6 \mathrm{~L}$ bench top fermentor (New Brunswick Scientific, Edison, New Jersey, USA.) with a $4 \mathrm{~L}$ working volume of diluted whey (DW) medium adjusted at an initial $\mathrm{pH}$ of 7.0 [76]. The flow rate was fixed at $0.5 \mathrm{~L} / \mathrm{h}$.

In the first re-alkalized fed-batch culture (fermentation I), two fresh substrates were used to feed the fermentor: a $400 \mathrm{~g} / \mathrm{L}$ concentrated lactose and a medium prepared with a concentrated whey $(\mathrm{CW})$. In the second fed-batch culture (fermentation II), the feeding substrate consisted of a mixture of a concentrated mussel processing waste (CMPW) medium and a $310 \mathrm{~g} / \mathrm{L}$ concentrated glucose. The two fedbatch cultures were inoculated with $2 \%(\mathrm{v} / \mathrm{v})$ of a $12 \mathrm{~h}$ culture of L. casei CECT 4043 in DW medium. The mean composition of the above mentioned culture media is shown in Table 5 [76].

These fermentations were carried out without $\mathrm{pH}$ control by repeatedly feeding and realkalizing the fermentor every $12 \mathrm{~h}$, until the strain CECT 4043 was unable to bring about the decrease of $\mathrm{pH}$. Samples $(100 \mathrm{~mL})$ were taken from the fermentation medium every $12 \mathrm{~h}$ starting from hour 12 , and analyzed to determine its total sugars (TS) concentration. After calculating the amounts of sugars consumed by the growing strain, the fermentor was fed with $100 \mathrm{~mL}$ of feeding substrate to restore the initial TS concentration in the fermentation medium. Immediately after feeding, the culture was re-alkalized up to $\mathrm{pH} 7.0$ with $4 \mathrm{M} \mathrm{NaOH}$.

Then, the initial fermentation volume at the beginning of each re-alkalization cycle in the two re-alkalized fed-batch cultures was calculated as:

$$
V_{t_{n}}=V_{t_{n-1}}+V \mathrm{NaOH}_{t_{n}},
$$

where $V$ and $V \mathrm{NaOH}$ are the volumes $(L)$ of fermentation medium and $4 \mathrm{M} \mathrm{NaOH}$.

The sum of the volumes of feeding substrates that must be added to the culture for restoring the initial TS in the fermentation medium are [221]:

$$
\begin{aligned}
V S_{t_{n-1}}=V \mathrm{~F}_{t_{n}}= & \left(V \mathrm{CL}_{t_{n}}+V C \mathrm{CW}_{t_{n}}\right) \\
& \text { for fermentation I, } \\
V \mathrm{~S}_{t_{n-1}}=V \mathrm{~F}_{t_{n}}= & \left(V \mathrm{CG}_{t_{n}}+V \mathrm{CMPW} t_{t_{n}}\right) \\
& \text { for fermentation II, }
\end{aligned}
$$


TABLE 5: Nutrients concentration (g/L) in the DW, CW, and CMPW media [76].

\begin{tabular}{lccc}
\hline Nutrients & DW & CW & CMPW \\
\hline Lactose & $20.27 \pm 0.27$ & $51.02 \pm 2.88$ & - \\
Glucose & - & - & $102.00 \pm 1.67$ \\
Proteins & $2.01 \pm 0.04$ & $5.05 \pm 0.05$ & $3.51 \pm 0.04$ \\
Total nitrogen & $0.50 \pm 0.06$ & $1.02 \pm 0.07$ & $0.78 \pm 0.06$ \\
Total phosphorous & $0.24 \pm 0.03$ & $0.43 \pm 0.02$ & $0.31 \pm 0.08$ \\
\hline
\end{tabular}

where $V F$ and $V S$ are the volumes $(L)$ of feeding and sampling, respectively. VCL, VCW, VCG, and VCMPW are, respectively, the volumes $(L)$ of concentrated lactose, CW medium, concentrated glucose, and CMPW medium added to the fermentor at the beginning of each feeding cycle.

Then, both the VCW and VCMPW were, respectively, calculated as:

$$
\begin{gathered}
V \mathrm{CW}_{t_{n}}=V \mathrm{~S}_{t_{n-1}}-V \mathrm{CL}_{t_{n}}, \\
V \mathrm{CMPW}_{t_{n}}=V \mathrm{~S}_{t_{n-1}}-V \mathrm{CG}_{t_{n}} .
\end{gathered}
$$

The reduction in the mass $(g)$ of TS in the fermentation medium due to the joint effect of the extraction of samples and the consumption of TS by the growing strain $\left(\mathrm{TS}_{C+E}\right)$ in both fermentations was calculated as:

$$
\begin{aligned}
\mathrm{TS}_{C+E}=V_{t_{n-1}} \cdot\left[\mathrm{TS}_{t_{n-1}}\right]-\left(V_{t_{n-1}}-V S_{t_{n}}\right) \cdot\left[\mathrm{TS}_{t_{n}}\right] \\
=V \mathrm{CW} \cdot\left[\mathrm{TS}_{\mathrm{CW}}\right]+V \mathrm{CL} \cdot\left[\mathrm{TS}_{\mathrm{CL}}\right] \\
\quad \text { for fermentation I, } \\
\mathrm{TS}_{C+E}=V_{t_{n-1}} \cdot\left[\mathrm{TS}_{t_{n-1}}\right]-\left(V_{t_{n-1}}-V \mathrm{~S}_{t_{n}}\right) \cdot\left[\mathrm{TS}_{t_{n}}\right] \\
=V \mathrm{CMPW} \cdot\left[\mathrm{TS}_{\mathrm{CMPW}}\right]+V \mathrm{CG} \cdot\left[\mathrm{TS}_{\mathrm{CG}}\right] \\
\text { for fermentation II, }
\end{aligned}
$$

where $\left[\mathrm{TS}_{t n-1}\right]$ and $\left[\mathrm{TS}_{t n}\right]$ are, respectively, the concentrations of total sugars $(\mathrm{g} / \mathrm{L})$ in the fermentation medium at the beginning $(20 \mathrm{~g} / \mathrm{L})$ and at the end of each feeding cycle. $\left[\mathrm{TS}_{\mathrm{CW}}\right],\left[\mathrm{TS}_{\mathrm{CMPW}}\right],\left[\mathrm{TS}_{\mathrm{CL}}\right]$, and $\left[\mathrm{TS}_{\mathrm{CG}}\right]$ are, respectively, the concentrations of total sugars in the CW $(51 \mathrm{~g} / \mathrm{L})$ and CMPW $(102 \mathrm{~g} / \mathrm{L})$ media and in the concentrated solutions of lactose $(400 \mathrm{~g} / \mathrm{L})$ and glucose $(310 \mathrm{~g} / \mathrm{L})$.

The VCL andVCG values can be calculated by substituting, respectively, (11) into (12), and then rearranging:

$$
\begin{gathered}
V \mathrm{CL}_{t_{n}}=\frac{\left(\mathrm{TS}_{\mathrm{C}+E}-V \mathrm{~S}_{t_{n-1}} \cdot\left[\mathrm{TS}_{\mathrm{CW}}\right]\right)}{\left(\left[\mathrm{TS}_{\mathrm{CL}}\right]-\left[\mathrm{TS}_{\mathrm{CW}}\right]\right)} \\
\text { for fermentation I, } \\
V \mathrm{CG}_{t_{n}}=\frac{\left(\mathrm{TS}_{\mathrm{C}+E}-V \mathrm{~S}_{t_{n-1}} \cdot\left[\mathrm{TS}_{\mathrm{CMPW}}\right]\right)}{\left(\left[\mathrm{TS}_{\mathrm{CG}}\right]-\left[\mathrm{TS}_{\mathrm{CMPW}}\right]\right)} \\
\text { for fermentation II. }
\end{gathered}
$$

The VCW and VCMPW values were obtained by introducing, respectively, the calculated values of VCL and VCG into (11).
The concentrations of biomass $(X)$ and products (AbA, LA, AA) in both fermentations, at the beginning of each re-alkalization cycle, just after the addition of the feeding substrates, were calculated by using the following equation:

$$
\begin{aligned}
& {[P]_{\text {beg }}=\frac{\left(V_{\text {end }}-V S_{\text {end }}\right) \cdot[P]_{\text {end }}}{V_{\text {beg }}},} \\
& \text { being } V_{\text {beg }}=V_{\text {end }}+V \mathrm{~F}+V N a O H
\end{aligned}
$$

where $[P]_{\text {end }}$ and $[P]_{\text {beg }}$ are, respectively, the biomass or product concentrations in the fermentor at the end of a realkalization and feeding cycle and at the beginning of the following cycle. The difference $\left(V_{\text {end }}-V S_{\text {end }}\right)$ represents the remaining volume of fermentation medium at the end of each re-alkalization and feeding cycle, justly after sampling. $V_{\text {beg }}$ is the volume of fermentation medium at the beginning of each feeding cycle, justly after feeding and re-alkalizing the medium with $4 \mathrm{M} \mathrm{NaOH}$.

The concentrations of nutrients (lactose, glucose, total nitrogen and phosphorous and proteins) at the beginning of each re-alkalization cycle in the fermentations I and II, were, respectively, calculated by using

$[S]_{\text {beg }}$

$=\frac{\left(V_{\text {end }}-V S_{\text {end }}\right) \cdot[S]_{\text {end }}+V C W_{\text {beg }} \cdot\left[S_{\mathrm{CW}}\right]+V C_{\text {beg }} \cdot\left[S_{\mathrm{CL}}\right]}{V_{\text {beg }}}$,

$[S]_{\text {beg }}$

$=\frac{\left(V_{\text {end }}-V S_{\text {end }}\right) \cdot[S]_{\text {end }}+V C M P W_{\text {beg }} \cdot\left[S_{\mathrm{CMPW}}\right]+V C_{\text {beg }} \cdot\left[S_{\mathrm{CG}}\right]}{V_{\text {beg }}}$,

where $[S]_{\text {end }}$ and $[S]_{\text {beg }}$ are, respectively, the nutrient concentrations in the fermentor at the end of a re-alkalization and feeding cycle and at the beginning of the following cycle. $\left[S_{\mathrm{CW}}\right],\left[S_{\mathrm{CMPW}}\right],\left[S_{\mathrm{CL}}\right]$, and $\left[S_{\mathrm{CG}}\right]$ are the nutrient concentrations in the feeding substrates (CW, CMPW, CL, and $C G)$.

\section{Conclusion}

Although in some cases the probiotic effects of lactococci and lactobacilli strains could not be clearly established, a great number of well-designed studies have shown the efficacy of these bacteria in humans and farm animals. However, a combination of practical knowledge on different disciplines, (e.g.,microbiology, statistics, molecular biology, and chemical engineering) is necessary to assure both the production and application of the probiotic LAB as dietary supplements in humans and animals.

With this knowledge, the probiotic properties of a strain could be adequately checked in vitro and in vivo in animal models. Secondly, the significant positive effect of a potential probiotic LAB in humans and animals could be rigorously confirmed by using well-designed trials. Thirdly, the economic viability of the large-scale production of highly concentrated cultures of probiotic LAB, with proven beneficial effects, could be ensured by optimizing the fermentation 
process. For the latter purpose, it is necessary to use of cheaper culture media in combination with an optimized fermentation procedure, and the development of an adequate control-system throughout the use of appropriate mathematical models describing the growth and product formation by probiotic LAB.

\section{Abbreviations}

$\begin{array}{ll}\text { A.: } & \text { Aeromonas } \\ \text { Ac.: } & \text { Acetobacter } \\ \text { Act.: } & \text { Actinomyces } \\ \text { Bac.: } & \text { Bacillus } \\ \text { B.: } & \text { Bifidobacterium } \\ \text { Br.: } & \text { Brochothrix } \\ \text { Camp.: } & \text { Campylobacter } \\ \text { C.: } & \text { Clostridium } \\ \text { Ent.: } & \text { Enterobacter or Enterococcus } \\ \text { E.: } & \text { Escherichia } \\ \text { H.: } & \text { Helicobacter } \\ \text { L.: } & \text { Lactobacillus; Listeria } \\ \text { Lact.: } & \text { Lactococcus } \\ \text { Leuc.: } & \text { Leuconostoc } \\ \text { M.: } & \text { Micrococcus } \\ \text { N.: } & \text { Nocardia } \\ \text { Ped.: } & \text { Pediococcus } \\ \text { Prop.: } & \text { Propionibacterium } \\ \text { P.: } & \text { Pseudomonas } \\ \text { Sacch.: } & \text { Saccharomyces } \\ \text { Salm.: } & \text { Salmonella } \\ \text { Sh.: } & \text { Shigella } \\ \text { Staph.: } & \text { Staphylococcus } \\ \text { S.: } & \text { Streptococcus } \\ \text { Y.: } & \text { Yersinia. } \\ & \end{array}$

\section{Acknowledgments}

The author wishes to thank the other members of his reseach team, Dr. Lorenzo Pastrana Castro and Dr. Ana Torrado Agrasar, for their kindest support in the elaboration of this work.

\section{References}

[1] M. I. Alvarez-Olmos and R. A. Oberhelman, "Probiotic agents and infectious diseases: a modern perspective on a traditional therapy," Clinical Infectious Diseases, vol. 32, no. 11, pp. 1567-1576, 2001.

[2] N. P. Guerra, P. F. Bernárdez, J. Méndez, P. Cachaldora, and L. Pastrana Castro, "Production of four potentially probiotic lactic acid bacteria and their evaluation as feed additives for weaned piglets," Animal Feed Science and Technology, vol. 134, no. 1-2, pp. 89-107, 2007.

[3] P. F. Bernárdez, C. F. González, J. M. Batán, L. P. Castro, and N. P. Guerra, "Performance and intestinal coliform counts in weaned piglets fed a probiotic culture (Lactobacillus casei subsp. casei CECT 4043) or an antibiotic," Journal of Food Protection, vol. 71, no. 9, pp. 1797-1805, 2008.

[4] M. Fujiya and Y. Kohgo, "Novel perspectives in probiotic treatment: the efficacy and unveiled mechanisms of the physiological functions," Clinical Journal of Gastroenterology, vol. 3, no. 3, pp. 117-127, 2010.

[5] G. E. Gardiner, P. G. Casey, G. Casey et al., "Relative ability of orally administered Lactobacillus murinus to predominate and persist in the porcine gastrointestinal tract," Applied and Environmental Microbiology, vol. 70, no. 4, pp. 1895-1906, 2004.

[6] M. C. Urdaci, P. Bressollier, and I. Pinchuk, "Bacillus clausii probiotic strains: antimicrobial and immunomodulatory activities," Journal of Clinical Gastroenterology, vol. 38, no. 6, supplement, pp. S86-90, 2004.

[7] T. Arvola, K. Laiho, S. Torkkeli et al., "Prophylactic lactobacillus GG reduces antibiotic-associated diarrhea in children with respiratory infections: a randomized study," Pediatrics, vol. 104, no. 5, article e64, 1999.

[8] M. Trop, M. Novak, S. Rodl, B. Hellbom, W. Kroell, and W. Goessler, "Silver-coated dressing acticoat caused raised liver enzymes and argyria-like symptoms in burn patient," The Journal of Trauma, vol. 60, no. 3, pp. 648-652, 2006.

[9] Joint FAO/WHO Working Group, Guidelines for the evaluation of probiotics in food: report of a Joint FAO/WHO Working Group on Drafting Guidelines for the Evaluation of Probiotics in Food, Ontario, Canada, 2002, http://www.who .int/foodsafety/fs_management/en/probiotic_guidelines.pdf.

[10] F. A. M. Klaver and R. van der Meer, "The assumed assimilation of cholesterol by lactobacilli and Bifidobacterium bifidum is due to their bile salt-deconjugating activity," Applied and Environmental Microbiology, vol. 59, no. 4, pp. 11201124, 1993.

[11] S. Salminen, "Uniqueness of probiotic strains," IDF Nutrition News-Letter, vol. 5, pp. 16-18, 1996.

[12] C. Dunne, L. O'Mahony, L. Murphy et al., "In vitro selection criteria for probiotic bacteria of human origin: correlation with in vivo findings," American Journal of Clinical Nutrition, vol. 73, no. 2, pp. 386S-392S, 2001.

[13] I. P. Kaur, K. Chopra, and A. Saini, "Probiotics: potential pharmaceutical applications," European Journal of Pharmaceutical Sciences, vol. 15, no. 1, pp. 1-9, 2002.

[14] R. Martín, N. Soberón, M. Vaneechoutte, A. B. Flórez, F. Vázquez, and J. E. Suárez, "Characterization of indigenous vaginal lactobacilli from healthy women as probiotic candidates," International Microbiology, vol. 11, no. 4, pp. 261-266, 2008.

[15] A. B. Rey-Morán, M. P. González-Abad, M. S. PérezRodríguez, E. M. Martínez-Vázquez, A. I. Tizón-Varela, and N. Pérez-Guerra, "Probiotic and health effects of lactobacillus strains in humans," in Lactobacillus: Classification, Uses and Health Implications, A. I. Perez-Campos and A. Leon-Mena, Eds., Nova Publishers, New York, NY, USA, 2012.

[16] J. R. Saltzman, R. M. Russell, B. Golner, S. Barakat, G. E. Dallal, and B. R. Goldin, "A randomized trial of Lactobacillus acidophilus BG2FO4 to treat lactose intolerance," American Journal of Clinical Nutrition, vol. 69, no. 1, pp. 140-146, 1999.

[17] S. A. Sarker, S. Sultana, G. J. Fuchs et al., "Lactobacillus paracasei strain ST11 has no effect on rotavirus but ameliorates the outcome of nonrotavirus diarrhea in children from Bangladesh," Pediatrics, vol. 116, no. 2, pp. e221-e228, 2005.

[18] K. Kukkonen, E. Savilahti, T. Haahtela et al., "Probiotics and prebiotic galacto-oligosaccharides in the prevention of allergic diseases: a randomized, double-blind, placebo-controlled trial," Journal of Allergy and Clinical Immunology, vol. 119, no. 1, pp. 192-198, 2007.

[19] A. L. Taylor, J. A. Dunstan, and S. L. Prescott, "Probiotic supplementation for the first 6 months of life fails to reduce 
the risk of atopic dermatitis and increases the risk of allergen sensitization in high-risk children: A randomized controlled trial," Journal of Allergy and Clinical Immunology, vol. 119, no. 1, pp. 184-191, 2007.

[20] V. Delcenserie, D. Martel, M. Lamoureux, J. Amiot, Y. Boutin, and D. Roy, "Immunomodulatory effects of probiotics in the intestinal tract," Current Issues in Molecular Biology, vol. 10, no. 1, pp. 37-54, 2008.

[21] M. Rautio, H. Jousimies-Somer, H. Kauma et al., "Liver abscess due to a Lactobacillus rhamnosus strain indistinguishable from L. rhamnosus Strain GG," Clinical Infectious Diseases, vol. 28, no. 5, pp. 1159-1160, 1999.

[22] J. P. Cannon, T. A. Lee, J. T. Bolanos, and L. H. Danziger, "Pathogenic relevance of lactobacillus: a retrospective review of over 200 cases," European Journal of Clinical Microbiology and Infectious Diseases, vol. 24, no. 1, pp. 31-40, 2005.

[23] M. E. Falagas, G. I. Betsi, and S. Athanasiou, "Probiotics for prevention of recurrent vulvovaginal candidiasis: a review," Journal of Antimicrobial Chemotherapy, vol. 58, no. 2, pp. 266-272, 2006.

[24] C. M. Slover and L. Danziger, "Lactobacillus: a review," Clinical Microbiology Newsletter, vol. 30, no. 4, pp. 23-27, 2008.

[25] A. D. Mackay, M. B. Taylor, C. C. Kibbler, and J. M. T. Hamilton-Miller, "Lactobacillus endocarditis caused by a probiotic organism," Clinical Microbiology and Infection, vol. 5, no. 5, pp. 290-292, 1999.

[26] M. P. Ryan, M. C. Rea, C. Hill, and R. P. Ross, "An application in cheddar cheese manufacture for a strain of Lactococcus lactis producing a novel broad-spectrum bacteriocin, lacticin 3147," Applied and Environmental Microbiology, vol. 62, no. 2, pp. 612-619, 1996.

[27] A. Geis, J. Singh, and M. Teuber, "Potential of lactic streptococci to produce bacteriocin," Applied and Environmental Microbiology, vol. 45, no. 1, pp. 205-211, 1983.

[28] W. Kozak, J. Bardowski, and W. T. Dobrzanski, "Lactostrepcin, a bacteriocin produced by Streptococcus lactis," Bulletin of the Academy of Sciences, vol. 45, pp. 217-221, 1977.

[29] W. Kozak, J. Bardowski, and W. T. Dobrzański, "Lactostrepcins-acid bacteriocins produced by lactic streptococci," Journal of Dairy Research, vol. 45, no. 2, pp. 247-257, 1978.

[30] J. C. Piard, F. Delorme, G. Giraffa, J. Commissarie, and M. Desmezeaud, "Evidence for a bacteriocin produced by Lactococcus lactis CNRZ 481," Netherlands Milk and Dairy Journal, vol. 44, no. 3-4, pp. 143-158, 1990.

[31] J. C. Piard, P. M. Muriana, M. J. Desmazeaud, and T. R. Klaenhammer, "Purification and partial characterization of lacticin 481, a lanthionine-containing bacteriocin produced by Lactococcus lactis subsp. lactis CNRZ 481," Applied and Environmental Microbiology, vol. 58, no. 1, pp. 279-284, 1992.

[32] A. T. R. Mattick and A. Hirsch, "A powerful inhibitory substance produced by group N Streptococci," Nature, vol. 154, no. 3913 , p. 551, 1944.

[33] A. T. R. Mattick and A. Hirsch, "Futher observations on an inhibitory substance (nisin) from Streptococci lactis," The Lancet, vol. 250, no. 6462, pp. 5-8, 1947.

[34] G. W. Buchman, S. Banerjee, and J. N. Hansen, "Structure, expression, and evolution of a gene encoding the precursor of nisin, a small protein antibiotic," The Journal of Biological Chemistry, vol. 263, no. 31, pp. 16260-16266, 1988.

[35] J. W. M. Mulders, I. J. Boerrigter, H. S. Rollema, R. J. Siezen, and W. M. de Vos, "Identification and characterization of the lantibiotic nisin Z, a natural nisin variant," European Journal of Biochemistry, vol. 201, no. 3, pp. 581-584, 1991.
[36] S. F. Barefoot and T. R. Klaenhammer, "Detection and activity of lactacin B, a bacteriocin produced by Lactobacillus acidophilus," Applied and Environmental Microbiology, vol. 45, no. 6, pp. 1808-1815, 1983.

[37] T. Tahara, M. Oshimura, C. Umezawa, and K. Kanatani, "Isolation, partial characterization, and mode of action of acidocin J1132, a two-component bacteriocin produced by Lactobacillus acidophilus JCM 1132," Applied and Environmental Microbiology, vol. 62, no. 3, pp. 892-897, 1996.

[38] T. Tahara, K. Kanatani, K. Yoshida, H. Miura, M. Sakamoto, and M. Oshimura, "Purification and some properties of acidocin 8912, a novel bacteriocin produced by Lactobacillus acidophilus TK8912," Bioscience, Biotechnology, and Biochemistry, vol. 56, no. 8, pp. 648-651, 1992.

[39] B. Bogovič-Matijašić and I. Rogelj, "Bacteriocin complex of Lactobacillus acidophilus LF221 - production studies in MRS media at different $\mathrm{pH}$ values and effect against Lactobacillus helveticus ATCC 15009," Process Biochemistry, vol. 33, no. 3, pp. 345-352, 1998.

[40] M. Rammelsberg and F. Radler, "Antibacterial polypeptides of lactobacillus species," Journal of Applied Bacteriology, vol. 69, no. 2, pp. 177-184, 1990.

[41] G. V. Reddy and K. M. Shahani, "Isolation of an antibiotic from Lactobacillus bulgaricus," Journal of Dairy Science, vol. 54, no. 5, pp. 748-752, 1971.

[42] N. Abdel-Bar, N. D. Harris, and R. L. Rill, "Purification and properties of an antimicrobial substance produced by Lactobacillus bulgaricus," Journal of Food Science, vol. 52, no. 2, pp. 411-415, 1987.

[43] P. S. Tichaczek, J. Nissen-Meyer, I. F. Nes, R. F. Vogel, and W. P. Hammes, "Characterization of the bacteriocins curvacin A from Lactobacillus curvatus LTH1174 and sakacin P from Lactobacillus sake LTH673," Systematic and Applied Microbiology, vol. 15 , no. 3, pp. 460-468, 1992.

[44] D. Casla, T. Requena, and R. Gomez, "Antimicrobial activity of lactic acid bacteria isolated from goat's milk and artisanal cheeses: characteristics of a bacteriocin produced by Lactobacillus curvatus IFPL 105," Journal of Applied Bacteriology, vol. 81, no. 1, pp. 35-41, 1996.

[45] T. Toba, E. Yoshioka, and T. Itoh, "Lacticin, a bacteriocin produced by Lactobacillus delbrueckii subsp. lactis," Letters in Applied Microbiology, vol. 12, no. 2, pp. 43-45, 1991.

[46] H. C. de Klerk and J. N. Coetzee, "Antibiosis among lactobacilli," Nature, vol. 192, no. 4800, pp. 340-341, 1961.

[47] T. R. Yan and C. S. Lee, "Characterization of a partially purified bacteriocin, fermentcin B, from Lactobacillus fermentum," Biotechnology Letters, vol. 19, no. 8, pp. 741-744, 1997.

[48] Y. Kawai, T. Saito, T. Toba, S. K. Samant, and T. Itoh, "Isolation and characterization of a highly hydrophobic new bacteriocin (gassericin A) from Lactobacillus gasseri LA39," Bioscience, Biotechnology and Biochemistry, vol. 58, no. 7, pp. 1218-1221, 1994.

[49] M. C. Joerger and T. R. Klaenhammer, "Cloning, expression, and nucleotide sequence of the Lactobacillus helveticus 481 gene encoding the bacteriocin helveticin J," Journal of Bacteriology, vol. 172, no. 11, pp. 6339-6347, 1990.

[50] E. E. Vaughan, C. Daly, and G. F. Fitzgerald, "Identification and characterization of helveticin V-1829, a bacteriocin produced by Lactobacillus helveticus 1829," Journal of Applied Bacteriology, vol. 73, no. 4, pp. 299-308, 1992.

[51] P. M. Muriana and T. R. Klaenhammer, "Purification and partial characterization of lactacin $\mathrm{F}$, a bacteriocin produced 
by Lactobacillus acidophilus 11088," Applied and Environmental Microbiology, vol. 57, no. 1, pp. 114-121, 1991.

[52] M. A. Daeschel, M. C. McKenney, and L. C. McDonald, "Bacteriocidal activity of Lactobacillus plantarum C-11," Food Microbiology, vol. 7, no. 2, pp. 91-98, 1990.

[53] E. L. Anderssen, D. B. Diep, I. F. Nes, V. G. H. Eijsink, and J. Nissen-Meyer, "Antagonistic activity of Lactobacillus plantarum C11: two new two-peptide bacteriocins, plantaricins $\mathrm{EF}$ and JK, and the induction factor plantaricin A," Applied and Environmental Microbiology, vol. 64, no. 6, pp. 22692272, 1998.

[54] B. Gonzalez, P. Arca, B. Mayo, and J. E. Suarez, "Detection, purification, and partial characterization of plantaricin C, a bacteriocin produced by a Lactobacillus plantarum strain of dairy origin," Applied and Environmental Microbiology, vol. 60, no. 6, pp. 2158-2163, 1994.

[55] S. K. Stephens, B. Floriano, D. P. Cathcart et al., "Molecular analysis of the locus responsible for production of plantaricin $\mathrm{S}$, a two-peptide bacteriocin produced by Lactobacillus plantarum LPCO10," Applied and Environmental Microbiology, vol. 64, no. 5, pp. 1871-1877, 1998.

[56] T. Toba, E. Yoshioka, and T. Itoh, "Acidophilucin A, a new heat-labile bacteriocin produced by Lactobacillus acidophilus LAPT 1060," Letters in Applied Microbiology, vol. 12, no. 4, pp. 106-108, 1991.

[57] U. Schillinger and F. K. Lücke, "Antibacterial activity of Lactobacillus sake isolated from meat," Applied and Environmental Microbiology, vol. 55, no. 8, pp. 1901-1906, 1989.

[58] J. Samelis, S. Roller, and J. Metaxopoulos, "Sakacin B, a bacteriocin produced by Lactobacillus sake isolated from Greek dry fermented sausages," Journal of Applied Bacteriology, vol. 76, no. 5, pp. 475-486, 1994.

[59] O. J. Sobrino, J. M. Rodriguez, W. L. Moreira, M. F. Fernandez, B. Sanz, and P. E. Hernandez, "Antibacterial activity of Lactobacillus sake isolated from dry fermented sausages," International Journal of Food Microbiology, vol. 13, no. 1, pp. 1-10, 1991.

[60] K. Arihara, S. Ogihara, T. Mukai, M. Itoh, and Y. Kondo, "Salivacin 140, a novel bacteriocin from Lactobacillus salivarius subsp. salicinius T140 active against pathogenic bacteria," Letters in Applied Microbiology, vol. 22, no. 6, pp. 420-424, 1996.

[61] R. Lejeune, R. Callewaert, K. Crabbé, and L. de Vuyst, "Modelling the growth and bacteriocin production by Lactobacillus amylovorus DCE 471 in batch cultivation," Journal of Applied Microbiology, vol. 84, no. 2, pp. 159-168, 1998.

[62] J. Wan, M. W. Hickey, and M. J. Coventry, "Continuous production of bacteriocins, brevicin, nisin gand pediocin, using calcium alginate-immobilized bacteria," Journal of Applied Bacteriology, vol. 79, no. 6, pp. 671-676, 1995.

[63] G. M. Vignolo, M. N. de Kairuz, A. A. P. de Ruiz Holgado, and G. Oliver, "Influence of growth conditions on the production of lactocin 705, a bacteriocin produced by Lactobacillus casei CRL 705," Journal of Applied Bacteriology, vol. 78, no. 1, pp. 5-10, 1995.

[64] G. Moll, T. Ubbink-Kok, H. Hildeng-Hauge et al., "Lactococcin $\mathrm{G}$ is a potassium ion-conducting, two-component bacteriocin," Journal of Bacteriology, vol. 178, no. 3, pp. 600 605, 1996.

[65] R. Yang, M. C. Johnson, and B. Ray, "Novel method to extract large amounts of bacteriocins from lactic acid bacteria," Applied and Environmental Microbiology, vol. 58, no. 10, pp. 3355-3359, 1992.
[66] R. Yang and B. Ray, "Factors influencing production of bacteriocins by lactic acid bacteria," Food Microbiology, vol. 11, no. 4, pp. 281-291, 1994.

[67] N. P. Guerra and L. Pastrana, "Modelling the influence of $\mathrm{pH}$ on the kinetics of both nisin and pediocin production and characterization of their functional properties," Process Biochemistry, vol. 37, no. 9, pp. 1005-1015, 2002.

[68] G. Enan and A. A. A. Amri, "Novel plantaricin UG1 production by Lactobacillus plantarum UG1 in enriched whey permeate in batch fermentation processes," Journal of Food, Agriculture and Environment, vol. 4, no. 2, pp. 85-88, 2006.

[69] F. Crispie, D. Twomey, J. Flynn, C. Hill, P. Ross, and W. Meaney, "The lantibiotic lacticin 3147 produced in a milkbased medium improves the efficacy of a bismuth-based teat seal in cattle deliberately infected with Staphylococcus aureus," Journal of Dairy Research, vol. 72, no. 2, pp. 159-167, 2005.

[70] P. Desjardins, J. Meghrous, and C. Lacroix, "Effect of aeration and dilution rate on nisin $\mathrm{Z}$ production during continuous fermentation with free and immobilized Lactococcus lactis UL719 in supplemented whey permeate," International Dairy Journal, vol. 11, no. 11-12, pp. 943-951, 2001.

[71] M. N. Amiali, C. Lacroix, and R. E. Simard, "High nisin Z production by Lactococcus lactis UL719 in whey permeate with aeration," World Journal of Microbiology and Biotechnology, vol. 14, no. 6, pp. 887-894, 1998.

[72] F. Goulhen, J. Meghrous, and C. Lacroix, "Production of a nisin $\mathrm{Z} /$ pediocin mixture by $\mathrm{pH}$-controlled mixed-strain batch cultures in supplemented whey permeate," Journal of Applied Microbiology, vol. 86, no. 3, pp. 399-406, 1999.

[73] N. P. Guerra, M. L. Rua, and L. Pastrana, "Nutritional factors affecting the production of two bacteriocins from lactic acid bacteria on whey," International Journal of Food Microbiology, vol. 70, no. 3, pp. 267-281, 2001.

[74] N. P. Guerra and L. Pastrana, "Influence of $\mathrm{pH}$ drop on both nisin and pediocin production by Lactococcus lactis and Pediococcus acidilactici," Letters in Applied Microbiology, vol. 37, no. 1, pp. 51-55, 2003.

[75] N. P. Guerra and L. P. Castro, "Enhancement of nisin production by Lactococcus lactis in periodically re-alkalized cultures," Biotechnology and Applied Biochemistry, vol. 38, no. 2, pp. 157-167, 2003.

[76] N. P. Guerra, Fajardo, and P. Pastrana L, "Strategies for low-cost production and modeling of highly concentrated cultures of Lactobacillus casei CECT, 4043," in Lactobacillus: Classification, Uses and Health Implications, A. I. PerezCampos and A. Leon-Mena, Eds., Nova Publishers, Hauppauge, NY, USA, 2012.

[77] M. K. Salminen, S. Tynkkynen, H. Rautelin et al., "Lactobacillus bacteremia during a rapid increase in probiotic use of Lactobacillus rhamnosus GG in Finland," Clinical Infectious Diseases, vol. 35, no. 10, pp. 1155-1160, 2002.

[78] H. Szajewska and J. Z. Mrukowicz, "Probiotics in the treatment and prevention of acute infectious diarrhea in infants and children: a systematic review of published randomized, double-blind, placebo-controlled trials," Journal of Pediatric Gastroenterology and Nutrition, vol. 33, no. 4, pp. S17-S25, 2001.

[79] H. J. Kim, M. Camilleri, S. McKinzie et al., "A randomized controlled trial of a probiotic, VSL\#3, on gut transit and symptoms in diarrhoea-predominant irritable bowel syndrome," Alimentary Pharmacology and Therapeutics, vol. 17, no. 7, pp. 895-904, 2003.

[80] M. Hickson, A. L. D'Souza, N. Muthu et al., "Use of probiotic lactobacillus preparation to prevent diarrhoea associated with 
antibiotics: randomised double blind placebo controlled trial," British Medical Journal, vol. 335, no. 7610, pp. 80-83, 2007.

[81] H. S. Kim and S. E. Gilliland, "Lactobacillus acidophilus as a dietary adjunct for milk to aid lactose digestion in humans," Journal of Dairy Science, vol. 66, no. 5, pp. 959-966, 1983.

[82] R. G. Montes, T. M. Bayless, J. M. Saavedra, and J. A. Perman, "Effect of milks inoculated with Lactobacillus acidophilus or a yogurt starter culture in lactose-maldigesting children," Journal of Dairy Science, vol. 78, no. 8, pp. 1657-1664, 1995.

[83] M. de Vrese, P. Rautenberg, C. Laue, M. Koopmans, T. Herremans, and J. Schrezenmeir, "Probiotic bacteria stimulate virus-specific neutralizing antibodies following a booster polio vaccination," European Journal of Nutrition, vol. 44, no. 7, pp. 406-413, 2005.

[84] H. Majamaa and E. Isolauri, "Probiotics: a novel approach in the management of food allergy," Journal of Allergy and Clinical Immunology, vol. 99, no. 2, pp. 179-185, 1997.

[85] A. W. Bruce and G. Reid, "Intravaginal instillation of lactobacilli for prevention of recurrent urinary tract infections," Canadian Journal of Microbiology, vol. 34, no. 3, pp. 339-343, 1988.

[86] E. Hilton, H. D. Isenberg, P. Alperstein, K. France, and M. T. Borenstein, "Ingestion of yogurt containing Lactobacillus acidophilus as prophylaxis for candidal vaginitis," Annals of Internal Medicine, vol. 116, no. 5, pp. 353-357, 1992.

[87] R. D. Wagner, C. Pierson, T. Warner et al., "Biotherapeutic effects of probiotic bacteria on candidiasis in immunodeficient mice," Infection and Immunity, vol. 65, no. 10, pp. 41654172, 1997.

[88] I. Stamatova, K. Kari, and H. Meurman, "In vitro evaluation of antimicrobial activity of putative probiotic lactobacilli against oral pathogens," International Journal of Probiotics and Prebiotics, vol. 2, no. 4, pp. 225-232, 2007.

[89] Y. Aso and H. Akazan, "Prophylactic effect of a Lactobacillus casei preparation on the recurrence of superficial bladder cancer," Urologia Internationalis, vol. 49, no. 3, pp. 125-129, 1992.

[90] Y. Aso, H. Akaza, T. Kotake, T. Tsukamoto, K. Imai, and S. Naito, "Preventive effect of a Lactobacillus casei preparation on the recurrence of superficial bladder cancer in a doubleblind trial," European Urology, vol. 27, no. 2, pp. 104-109, 1995.

[91] A. Ait-Belgnaoui, H. Eutamene, E. Houdeau, L. Bueno, J. Fioramonti, and V. Theodorou, "Lactobacillus farciminis treatment attenuates stress-induced overexpression of Fos protein in spinal and supraspinal sites after colorectal distension in rats," Neurogastroenterology and Motility, vol. 21, no. 5, pp. 567.e19-573.e19, 2009.

[92] L. O’Mahony, J. Mccarthy, P. Kelly et al., "Lactobacillus and Bifidobacterium in irritable bowel syndrome: symptom responses and relationship to cytokine profiles," Gastroenterology, vol. 128, no. 3, pp. 541-551, 2005.

[93] W. Kruis, P. Frič, J. Pokrotnieks et al., "Maintaining remission of ulcerative colitis with the probiotic Escherichia coli Nissle 1917 is as effective as with standard mesalazine," Gut, vol. 53, no. 11, pp. 1617-1623, 2004.

[94] A. Roessler, U. Friedrich, H. Vogelsang et al., "The immune system in healthy adults and patients with atopic dermatitis seems to be affected differently by a probiotic intervention," Clinical and Experimental Allergy, vol. 38, no. 1, pp. 93-102, 2008.

[95] B. Bogovič-Matijašić, S. Stojković, J. Salobir, S. Malovrh, and I. Rogelj, "Evaluation of the Lactobacillus gasseri K7 and
LF221 strains in weaned piglets for their possible probiotic use and their detection in the faeces," Animal Research, vol. 53, no. 1, pp. 35-44, 2004.

[96] F. Abe, N. Ishibashi, and S. Shimamura, "Effect of administration of bifidobacteria and lactic acid bacteria to newborn calves and piglets," Journal of Dairy Science, vol. 78, no. 12, pp. 2838-2846, 1995.

[97] F. Tortuero, J. Rioperez, E. Fernandez, and M. L. Rodriguez, "Response of Piglets to oral administration of lactic acid bacteria," Journal of Food Protection, vol. 58, no. 12, pp. 13691374, 1995.

[98] Y. H. Chang, J. K. Kim, H. J. Kim, W. Y. Kim, Y. B. Kim, and Y. H. Park, "Selection of potential probiotic lactobacillus strain and subsequent in vivo studies," Antonie van Leeuwenhoek, vol. 80, no. 2, pp. 193-199, 2001.

[99] Q. Shu, F. Qu, and H. S. Gill, "Probiotic treatment using Bifidobacterium lactis HN019 reduces weanling diarrhea associated with rotavirus and Escherichia coli infection in a piglet model," Journal of Pediatric Gastroenterology and Nutrition, vol. 33, no. 2, pp. 171-177, 2001.

[100] G. Gardiner, C. Stanton, P. B. Lynch, J. K. Collins, G. Fitzgerald, and R. P. Ross, "Evaluation of cheddar cheese as a food carrier for delivery of a probiotic strain to the gastrointestinal tract," Journal of Dairy Science, vol. 82, no. 7, pp. 1379-1387, 1999.

[101] P. G. Falk, L. V. Hooper, T. Midtvedt, and J. I. Gordon, "Creating and maintaining the gastrointestinal ecosystem: what we know and need to know from gnotobiology," Microbiology and Molecular Biology Reviews, vol. 62, no. 4, pp. 1157-1170, 1998.

[102] Y. Umesaki and H. Setoyama, "Structure of the intestinal flora responsible for development of the gut immune system in a rodent model," Microbes and Infection, vol. 2, no. 11, pp. 1343-1351, 2000.

[103] M. Pollmann, M. Nordhoff, A. Pospischil, K. Tedin, and L. H. Wieler, "Effects of a probiotic strain of Enterococcus faecium on the rate of natural Chlamydia infection in swine," Infection and Immunity, vol. 73, no. 7, pp. 4346-4353, 2005.

[104] A. G. Lorenzoni, S. Pasteiner, M. Mohnl, and F. Perazzo, "Probiotics: challenging the traditional modes of action," Iranian Journal of Animal Science, vol. 2, pp. 33-37, 2012.

[105] M. Gobbetti, P. Ferranti, E. Smacchi, F. Goffredi, and F. Addeo, "Production of angiotensin-I-converting-enzymeinhibitory peptides in fermented milks started by Lactobacillus delbrueckii subsp. bulgaricus SS1 and Lactococcus lactis subsp. cremoris FT4," Applied and Environmental Microbiology, vol. 66, no. 9, pp. 3898-3904, 2000.

[106] S. D. Todorov, S. T. Danova, C. A. van Reenen et al., "Characterization of bacteriocin HV219, produced by Lactococcus lactis subsp. lactis HV219 isolated from human vaginal secretions," Journal of Basic Microbiology, vol. 46, no. 3, pp. 226-238, 2006.

[107] S. D. Todorov, M. Botes, S. T. Danova, and L. M. T. Dicks, "Probiotic properties of Lactococcus lactis ssp. lactis HV219, isolated from human vaginal secretions," Journal of Applied Microbiology, vol. 103, no. 3, pp. 629-639, 2007.

[108] B. Kos, J. Šš̌ković, J. Goreta, and S. Matošić, "Effect of protectors on the viability of Lactobacillus acidophilus M92 in simulated gastrointestinal conditions," Food Technology and Biotechnology, vol. 38, no. 2, pp. 121-127, 2000.

[109] P. Fajardo, L. Pastrana, J. Méndez, I. Rodríguez, C. Fuciños, and N. P. Guerra, "Effects of feeding of two potentially probiotic preparations from lactic acid bacteria on the performance and faecal microflora of broiler chickens," The 
Scientific World Journal, vol. 2012, Article ID 562635, 9 pages, 2012.

[110] L. Z. Jin, R. R. Marquardt, and X. Zhao, "A strain of Enterococcus faecium (18C23) inhibits adhesion of enterotoxigenic Escherichia coli K88 to porcine small intestine mucus," Applied and Environmental Microbiology, vol. 66, no. 10, pp. 4200-4204, 2000.

[111] G. Perdigon, S. Alvarez, M. Rachid, G. Agüero, and N. Gobbato, "Immune system stimulation by probiotics," Journal of Dairy Science, vol. 78, no. 7, pp. 1597-1606, 1995.

[112] G. Perdigón, M. Locascio, M. Medici, A. P. de Ruiz Holgado, and G. Oliver, "Interaction of bifidobacteria with the gut and their influence in the immune function," Biocell, vol. 27, no. 1, pp. 1-9, 2003.

[113] L. Saavedra, M. Pía Taranto, F. Sesma, and G. Font de Valdez, "Home-made traditional cheeses for the isolation of probiotic Enterococcus faecium strains," International Journal of Food Microbiology, vol. 88, no. 2-32, pp. 241-245, 2003.

[114] J. R. Vakil and K. M. Shahani, "Partial purification of antibacterial activity of Lactobacillus acidophilus," Bacteriological Proceedings, vol. 9, pp. 122-124, 1965.

[115] H. Lee, B. A. Friend, and K. M. Shahani, "Factors affecting the protein quality of yogurt and acidophilus milk," Journal of Dairy Science, vol. 71, no. 12, pp. 3203-3213, 1988.

[116] C. F. Fernandes, K. M. Shahani, and M. A. Amer, "Therapeutic role of dietary lactobacilli and lactobacillic fermented dairy products," FEMS Microbiology Letters, vol. 46, no. 3, pp. 343-356, 1987.

[117] S. K. Dash, "Review of scientific evidence for efficacy of Lactobacillus acidophilus DDS-1 as a probiotic strain," Agro Food Industry Hi-Tech, vol. 15, no. 5, pp. 23-26, 2004.

[118] A. Chatterjee, T. Yasmin, D. Bagchi, and S. J. Stohs, "The bactericidal effects of Lactobacillus acidophilus, garcinol and Protykin compared to clarithromycin, on Helicobacter pylori," Molecular and Cellular Biochemistry, vol. 243, no. 1-2, pp. 29-35, 2003.

[119] H. Lee, N. Rangavajhyala, C. Grandjean, and K. M. Shahani, "Anticarcinogenic effect of Lactobacillus acidophilus on Nnitrosobis(2-oxopropyl)amine induced colon tumor in rats," Journal of Applied Nutrition, vol. 48, no. 3, pp. 59-66, 1996.

[120] N. Rangavajhyala, K. M. Shahani, G. Sridevi, and S. Srikumaran, "Nonlipopolysaceharide component(s) of Lactobacillus acidophilus stimulate(s) the production of interleukin$1 \alpha$ and tumor necrosis factor- $\alpha$ by murine macrophages," Nutrition and Cancer, vol. 28, no. 2, pp. 130-134, 1997.

[121] M. F. Bernet, D. Brassart, J. R. Neeser, and A. L. Servin, "Lactobacillus acidophilus LA 1 binds to cultured human intestinal cell lines and inhibits cell attachment and cell invasion by enterovirulent bacteria," Gut, vol. 35, no. 4, pp. 483-489, 1994.

[122] M. F. Bernet-Camard, V. Liévin, D. Brassart, J. R. Neeser, A. L. Servin, and S. Hudault, "The human Lactobacillus acidophilus strain LA1 secretes a nonbacteriocin antibacterial subtance(s) active in vitro and in vivo," Applied and Environmental Microbiology, vol. 63, no. 7, pp. 2747-2753, 1997.

[123] J. H. Chang, Y. Y. Shim, S. K. Cha, M. J. Reaney, and K. M. Chee, "Effect of Lactobacillus acidophilus KFRI342 on the development of chemically induced precancerous growths in the rat colon," Journal of Medical Microbiology, vol. 61, no. 3, pp. 361-368, 2012.

[124] R. Tabasco, T. García-Cayuela, C. Peláez, and T. Requena, "Lactobacillus acidophilus La-5 increases lactacin B production when it senses live target bacteria," International Journal of Food Microbiology, vol. 132, no. 2-3, pp. 109-116, 2009.
[125] P. K. Jain, C. E. McNaught, A. D. G. Anderson, J. MacFie, and C. J. Mitchell, "Influence of synbiotic containing Lactobacillus acidophilus La5, Bifidobacterium lactis $\mathrm{Bb} 12$, Streptococcus thermophilus, Lactobacillus bulgaricus and oligofructose on gut barrier function and sepsis in critically ill patients: a randomised controlled trial," Clinical Nutrition, vol. 23, no. 4, pp. 467-475, 2004.

[126] S. Wildt, L. K. Munck, L. Vinter-Jensen et al., "Probiotic treatment of collagenous colitis: a randomized, double-blind, placebo-controlled trial with Lactobacillus acidophilus and Bifidobacterium animalis subsp. lactis," Inflammatory Bowel Diseases, vol. 12, no. 5, pp. 395-401, 2006.

[127] B. S. Reddy, J. MacFie, M. Gatt, C. N. Larsen, S. S. Jensen, and T. D. Leser, "Randomized clinical trial of effect of synbiotics, neomycin and mechanical bowel preparation on intestinal barrier function in patients undergoing colectomy," British Journal of Surgery, vol. 94, no. 5, pp. 546-554, 2007.

[128] K. Y. Wang, S. N. Li, C. S. Liu et al., "Effects of ingesting lactobacillus- and Bifidobacterium-containing yogurt in subjects with colonized Helicobacter pylori," American Journal of Clinical Nutrition, vol. 80, no. 3, pp. 737-741, 2004.

[129] B. S. Sheu, H. C. Cheng, A. W. Kao et al., "Pretreatment with lactobacillus- and Bifidobacterium-containing yogurt can improve the efficacy of quadruple therapy in eradicating residual Helicobacter pylori infection after failed triple therapy," American Journal of Clinical Nutrition, vol. 83, no. 4, pp. 864-869, 2006.

[130] H. S. Ejtahed, J. Mohtadi-Nia, A. Homayouni-Rad et al., "Effect of probiotic yogurt containing Lactobacillus acidophilus and Bifidobacterium lactis on lipid profile in individuals with type 2 diabetes mellitus," Journal of Dairy Science, vol. 94, no. 7, pp. 3288-3294, 2011.

[131] U. Glück and J. O. Gebbers, "Ingested probiotics reduce nasal colonization with pathogenic bacteria (Staphylococcus aureus, Streptococcus pneumoniae, and $\beta$-hemolytic streptococci)," American Journal of Clinical Nutrition, vol. 77, no. 2, pp. 517-520, 2003.

[132] D. L. Oberreuther-Moschner, G. Jahreis, G. Rechkemmer, and B. L. Pool-Zobel, "Dietary intervention with the probiotics Lactobacillus acidophilus 145 Bifidobacterium longum 913 modulates the potential of human faecal water to induce damage in HT29clone19A cells," British Journal of Nutrition, vol. 91, no. 6, pp. 925-932, 2004.

[133] J. Metts, T. R. Famula, N. Trenev, and R. A. Clemens, "Lactobacillus acidophilus, strain NAS $\left(\mathrm{H}_{2} \mathrm{O}_{2}\right.$ Positive), in reduction of recurrent candidal vulvovaginitis," Journal of Applied Research, vol. 3, no. 4, pp. 340-348, 2003.

[134] M. E. Sanders and T. R. Klaenhammer, "Invited review. The scientific basis of Lactobacillus acidophilus NCFM functionality as a probiotic," Journal of Dairy Science, vol. 84, no. 2, pp. 319-331, 2001.

[135] S. E. Gilliland and M. L. Speck, "Antagonistic action of Lactobacillus acidophilus toward intestinal and foodborne pathogens in associative cultures," Journal of Food Protection, vol. 40, pp. 820-823, 1977.

[136] E. G. Kleeman and T. R. Klaenhammer, "Adherence of lactobacillus species to human fetal intestinal cells," Journal of Dairy Science, vol. 65, no. 11, pp. 2063-2069, 1982.

[137] J. D. Greene and T. R. Klaenhammer, "Factors involved in adherence of lactobacilli to human Caco-2 cells," Applied and Environmental Microbiology, vol. 60, no. 12, pp. 4487-4494, 1994.

[138] M. E. Sanders, D. C. Walker, K. M. Walker, K. Aoyama, and T. R. Klaenhammer, "Performance of commercial cultures in 
fluid milk applications," Journal of Dairy Science, vol. 79, no. 6, pp. 943-955, 1996.

[139] D. C. Crowell, Microbial analysis of human intestinal flora after feeding Lactobacillus acidophilus [M.S. thesis], North Carolina State University, Raleigh, NC, USA, 1998.

[140] B. R. Goldin and S. L. Gorbach, "Effect of Lactobacillus acidophilus dietary supplements on 1,2-dimethylhydrazine dihydrochloride-induced intestinal cancer in rats," Journal of the National Cancer Institute, vol. 64, no. 2, pp. 263-265, 1980.

[141] C. Rousseaux, X. Thuru, A. Gelot et al., "Lactobacillus acidophilus modulates intestinal pain and induces opioid and cannabinoid receptors," Nature Medicine, vol. 13, no. 1, pp. 35-37, 2007.

[142] K. A. Ryan, P. Daly, Y. Li, C. Hooton, and P. W. O’Toole, "Strain-specific inhibition of Helicobacter pylori by Lactobacillus salivarius and other lactobacilli," Journal of Antimicrobial Chemotherapy, vol. 61, no. 4, pp. 831-834, 2008.

[143] G. Chauvière, M. H. Coconnier, S. Kerméis, J. Fourniat, and A. L. Servin, "Adhesion of human Lactobacillus acidophilus strain LB to human enterocyte-like Caco-2 cells," Journal of General Microbiology, vol. 138, no. 8, pp. 1689-1696, 1992.

[144] M. H. Coconnier, M. F. Bernet, S. Kernéis, G. Chauvière, J. Fourniat, and A. L. Servin, "Inhibition of adhesion of enteroinvasive pathogens to human intestinal Caco-2 cells by Lactobacillus acidophilus strain LB decreases bacterial invasion," FEMS Microbiology Letters, vol. 110, no. 3, pp. 299305, 1993.

[145] M. H. Coconnier, V. Lievin, E. Hemery, and A. L. Servin, "Antagonistic activity against Helicobacter infection in vitro and in vivo by the human Lactobacillus acidophilus strain LB," Applied and Environmental Microbiology, vol. 64, no. 11, pp. 4573-4580, 1998.

[146] M. H. Coconnier, V. Liévin, M. Lorrot, and A. L. Servin, "Antagonistic activity of Lactobacillus acidophilus LB against intracellular Salmonella enterica serovar typhimurium infecting human enterocyte-like Caco-2/TC-7 cells," Applied and Environmental Microbiology, vol. 66, no. 3, pp. 1152-1157, 2000.

[147] V. L. L. Moal, R. Amsellem, A. L. Servin, and M. H. Coconnier, "Lactobacillus acidophilus (strain LB) from the resident adult human gastrointestinal microflora exerts activity against brush border damage promoted by a diarrhoeagenic Escherichia coli in human enterocyte-like cells," Gut, vol. 50, no. 6, pp. 803-811, 2002.

[148] V. L. L. Moal, L. E. Sarrazin-Davila, and A. L. Servin, "An experimental study and a randomized, double-blind, placebo-controlled clinical trial to evaluate the antisecretory activity of Lactobacillus acidophilus strain LB against nonrotavirus diarrhea," Pediatrics, vol. 120, no. 4, pp. e795-e803, 2007.

[149] A. R. Bodana and D. R. Rao, "Antimutagenic activity of milk fermented by Streptococcus thermophilus and Lactobacillus bulgaricus," Journal of Dairy Science, vol. 73, no. 12, pp. 33793384, 1990.

[150] M. C. Martini, E. C. Lerebours, W. J. Lin et al., "Strains and species of lactic acid bacteria in fermented milks (yogurts): effect on in vivo lactose digestion," American Journal of Clinical Nutrition, vol. 54, no. 6, pp. 1041-1046, 1991.

[151] H. Kitazawa, H. Watanabe, T. Shimosato, Y. Kawai, T. Itoh, and T. Saito, "Immunostimulatory oligonucleotide, CpG-like motif exists in Lactobacillus delbrueckii ssp. bulgaricus NIAI B6," International Journal of Food Microbiology, vol. 85, no. 1-2, pp. 11-21, 2003.
[152] A. P. Bai, Q. Ouyang, W. Zhang, C. H. Wang, and S. F. Li, "Probiotics inhibit TNF- $\alpha$-induced interleukin- 8 secretion of HT29 cells," World Journal of Gastroenterology, vol. 10, no. 3, pp. 455-457, 2004.

[153] K. Pedersen and G. W. Tannock, "Colonization of the porcine gastrointestinal tract by lactobacilli," Applied and Environmental Microbiology, vol. 55, no. 2, pp. 279-283, 1989.

[154] K. Pedersen, G. W. Christensen, M. Steffensen, P. Schyum, and A. K. Johansen, "Transfer of lactic acid bacterial strains from the feed to the sow, the environment, and the piglets," Acta Veterinaria Scandinavica, vol. 33, no. 4, pp. 297-303, 1992.

[155] I. Rogelj, B. Bogovič Matijaši, A. Anžek Majhenič, and S. Stojkovi, "The survival and persistence of Lactobacillus acidophilus LF221 in different ecosystems," International Journal of Food Microbiology, vol. 76, no. 1-2, pp. 83-91, 2002.

[156] R. de Waard, J. Garssen, G. C. A. M. Bokken, and J. G. Vos, "Antagonistic activity of Lactobacillus casei strain Shirota against gastrointestinal Listeria monocytogenes infection in rats," International Journal of Food Microbiology, vol. 73, no. 1, pp. 93-100, 2002.

[157] C. Koebnick, I. Wagner, P. Leitzmann, U. Stern, and H. J. F. Zunft, "Probiotic beverage containing Lactobacillus casei Shirota improves gastrointestinal symptoms in patients with chronic constipation," Canadian Journal of Gastroenterology, vol. 17, no. 11, pp. 655-659, 2003.

[158] D. Sgouras, P. Maragkoudakis, K. Petraki et al., "In vitro and in vivo inhibition of Helicobacter pylori by Lactobacillus casei strain Shirota," Applied and Environmental Microbiology, vol. 70, no. 1, pp. 518-526, 2004.

[159] K. Takeda and K. Okumura, "Effects of a fermented milk drink containing Lactobacillus casei strain Shirota on the human NK-cell activity," Journal of Nutrition, vol. 137, no. 3, pp. 791S-793S, 2007.

[160] P. P. Cáceres and M. Gotteland, "Probiotics in Chile: which are the strains and what are their effects on human health?" Revista Chilena de Nutricion, vol. 37, no. 1, pp. 97-109, 2010.

[161] D. Gaon, C. Garmendia, N. O. Murrielo et al., "Effect of lactobacillus strains (L. casei and L. acidophillus strains cerela) on bacterial overgrowth-related chronic diarrhea," Medicina, vol. 62, no. 2, pp. 159-163, 2002.

[162] D. Gaón, H. García, L. Winter et al., "Effect of lactobacillus strains and Saccharomyces boulardii on persistent diarrhea in children," Medicina, vol. 63, no. 4, pp. 293-298, 2003.

[163] C. Maldonado Galdeano and G. Perdigón, “The probiotic bacterium Lactobacillus casei induces activation of the gut mucosal immune system through innate immunity," Clinical and Vaccine Immunology, vol. 13, no. 2, pp. 219-226, 2006.

[164] T. von der Weid, C. Bulliard, and E. J. Schiffrin, "Induction by a lactic acid bacterium of a population of $\mathrm{CD} 4^{+} \mathrm{T}$ cells with low proliferative capacity that produce transforming growth factor $\beta$ and interleukin-10," Clinical and Diagnostic Laboratory Immunology, vol. 8, no. 4, pp. 695-701, 2001.

[165] E. F. Verdú, P. Bercik, M. Verma-Gandhu et al., "Specific probiotic therapy attenuates antibiotic induced visceral hypersensitivity in mice," Gut, vol. 55, no. 2, pp. 182-190, 2006.

[166] C. L. García-Ródenas, G. E. Bergonzelli, S. Nutten et al., "Nutritional approach to restore impaired intestinal barrier function and growth after neonatal stress in rats," Journal of Pediatric Gastroenterology and Nutrition, vol. 43, no. 1, pp. 16-24, 2006. 
[167] S. Cunningham-Rundles, S. Ahrné, S. Bengmark et al., "Probiotics and immune response," The American Journal of Gastroenterology, vol. 95, no. 1, pp. S22-S25, 2000.

[168] S. Nobaek, M. L. Johansson, G. Molin, S. Ahrné, and B. Jeppsson, "Alteration of intestinal microflora is associated with reduction in abdominal bloating and pain in patients with irritable bowel syndrome," The American Journal of Gastroenterology, vol. 95, no. 5, pp. 1231-1238, 2000.

[169] K. Niedzielin, H. Kordecki, and B. Birkenfeld, "A controlled, double-blind, randomized study on the efficacy of Lactobacillus plantarum $299 \mathrm{~V}$ in patients with irritable bowel syndrome," European Journal of Gastroenterology and Hepatology, vol. 13, no. 10, pp. 1143-1147, 2001.

[170] P. D. Sawant, J. Venkatraman, and P. Ducrotté, “T2030 evaluation of Lactobacillus plantarum 299v efficacy in IBS: results of a randomized placebo-controlled trial in 200 patients," The American Journal of Gastroenterology, vol. 139, no. 5, supplement 1, p. S-617, 2010.

[171] A. Oláh, T. Belágyi, Á. Issekutz, M. E. Gamal, and S. Bengmark, "Randomized clinical trial of specific lactobacillus and fibre supplement to early enteral nutrition in patients with acute pancreatitis," British Journal of Surgery, vol. 89, no. 9, pp. 1103-1107, 2002.

[172] N. Rayes, D. Seehofer, S. Hansen et al., "Early enteral supply of lactobacillus and fiber versus selective bowel decontamination: a controlled trial in liver transplant recipients," Transplantation, vol. 74, no. 1, pp. 123-128, 2002.

[173] N. Rayes, S. Hansen, D. Seehofer et al., "Early enteral supply of fiber and lactobacilli versus conventional nutrition: a controlled trial in patients with major abdominal surgery," Nutrition, vol. 18, no. 7-8, pp. 609-615, 2002.

[174] P. Mangell, P. Nejdfors, M. Wang et al., "Lactobacillus plantarum 299v inhibits Escherichia coli-induced intestinal permeability," Digestive Diseases and Sciences, vol. 47, no. 3, pp. 511-516, 2002.

[175] G. Ruiz-Palacios, M. L. Guerrero, and M. Hilty, "Feeding of a probiotic for the prevention of community-acquired diarrhea in young Mexican children," Pediatric Research, vol. 39, no. 4, part 2, p. 184, 1996.

[176] A. V. Shornikova, I. A. Casas, E. Isolauri, H. Mykkänen, and T. Vesikari, "Lactobacillus reuteri as a therapeutic agent in acute diarrhea in young children," Journal of Pediatric Gastroenterology and Nutrition, vol. 24, no. 4, pp. 399-404, 1997.

[177] A. V. Shornikova, I. A. Casas, H. Mykkänen, E. Salo, and T. Vesikari, "Bacteriotherapy with Lactobacillus reuteri in rotavirus gastroenteritis," Pediatric Infectious Disease Journal, vol. 16, no. 12, pp. 1103-1107, 1997.

[178] Z. Weizman, G. Asli, and A. Alsheikh, "Effect of a probiotic infant formula on infections in child care centers: comparison of two probiotic agents," Pediatrics, vol. 115, no. 1, pp. 5-9, 2005.

[179] E. Lionetti, V. L. Miniello, S. P. Castellaneta et al., "Lactobacillus reuteri therapy to reduce side-effects during antiHelicobacter pylori treatment in children: a randomized placebo controlled trial," Alimentary Pharmacology and Therapeutics, vol. 24, no. 10, pp. 1461-1468, 2006.

[180] F. Savino, E. Pelle, E. Palumeri, R. Oggero, and R. Miniero, "Lactobacillus reuteri (American type culture collection strain 55730) versus simethicone in the treatment of infantile colic: a prospective randomized study," Pediatrics, vol. 119, no. 1, pp. e124-e130, 2007.
[181] N. Valeur, P. Engel, N. Carbajal, E. Connolly, and K. Ladefoged, "Colonization and immunomodulation by Lactobacillus reuteri ATCC 55730 in the human gastrointestinal tract," Applied and Environmental Microbiology, vol. 70, no. 2, pp. 1176-1181, 2004.

[182] H. Nikawa, S. Makihira, H. Fukushima et al., "Lactobacillus reuteri in bovine milk fermented decreases the oral carriage of mutans Streptococci," International Journal of Food Microbiology, vol. 95, no. 2, pp. 219-223, 2004.

[183] A. Saggioro, M. Caroli, L. Girardi, G. Chiozzini, and M. Pasini, "Helicobacter pylori eradication with Lactobacillus reuteri. A double-blind placebo-controlled study," Digestive and Liver Disease, vol. 37, supplement 1, article S88, 2005.

[184] R. Francavilla, E. Lionetti, S. P. Castellaneta et al., "Inhibition of Helicobacter pylori infection in humans by Lactobacillus reuteri ATCC 55730 and effect on eradication therapy: a pilot study," Helicobacter, vol. 13, no. 2, pp. 127-134, 2008.

[185] T. R. Klaenhammer, "Bacteriocins of lactic acid bacteria," Biochimie, vol. 70, no. 3, pp. 337-349, 1988.

[186] R. K. Malik, N. Kumar, K. N. Rao, and D. K. Mathur, "Bacteriocins - antibacterial proteins of lactic acid bacteria: a review," Microbiologie, Aliments, Nutrition, vol. 12, pp. 117132, 1994.

[187] N. P. Guerra and L. P. Castro, "Production of bacteriocins from Lactococcus lactis subsp. lactis CECT 539 and Pediococcus acidilactici NRRL B-5627 using mussel-processing wastes," Biotechnology and Applied Biochemistry, vol. 36, no. 2, pp. 119-125, 2002.

[188] J. R. Tagg, A. S. Dajani, and L. W. Wannamaker, "Bacteriocins of gram positive bacteria," Bacteriological Reviews, vol. 40, no. 3, pp. 722-756, 1976.

[189] J. Delves-Broughton, "Nisin and its use as food preservative," Food Technology, vol. 44, pp. 100-117, 1990.

[190] P. Fajardo, C. Fuciños, I. Rodríguez, L. Pastrana, and N. P. Guerra, "Cheese whey utilization for bacteriocin production," in Advances in Cheese Whey Utilization, M. E. Cerdán, M. I. González-Siso, and M. Bacerra, Eds., pp. 163-193, Transworld Research Network, Kerala, India, 2008.

[191] P. F. Bernárdez, I. R. Amado, L. P. Castro, and N. P. Guerra, "Production of a potentially probiotic culture of Lactobacillus casei subsp. casei CECT 4043 in whey," International Dairy Journal, vol. 18, no. 10-11, pp. 1057-1065, 2008.

[192] N. P. Guerra, A. T. Agrasar, C. L. Macías, and L. Pastrana, "Modelling the fed-batch production of pediocin using mussel processing wastes," Process Biochemistry, vol. 40, no. 3-4, pp. 1071-1083, 2005.

[193] N. P. Guerra, P. F. Bernárdez, and L. P. Castro, "Fed-batch pediocin production on whey using different feeding media," Enzyme and Microbial Technology, vol. 41, no. 3, pp. 397-406, 2007.

[194] X. Liu, Y. K. Chung, S. T. Yang, and A. E. Yousef, "Continuous nisin production in laboratory media and whey permeate by immobilized Lactococcus lactis," Process Biochemistry, vol. 40, no. 1, pp. 13-24, 2005.

[195] A. L. Kaiser and T. J. Montville, "The influence of pH and growth rate on production of the bacteriocin, bavaricin $\mathrm{MN}$, in batch and continuous fermentations," Journal of Applied Bacteriology, vol. 75, no. 6, pp. 536-540, 1993.

[196] M. L. Cabo, M. A. Murado, M. P. González, and L. Pastoriza, "Effects of aeration and $\mathrm{pH}$ gradient on nisin production. A mathematical model," Enzyme and Microbial Technology, vol. 29, no. 4-5, pp. 264-273, 2001.

[197] J. A. Vázquez, M. L. Cabo, M. P. González, and M. A. Murado, "The role of amino acids in nisin and pediocin production 
by two lactic acid bacteria: a factorial study," Enzyme and Microbial Technology, vol. 34, no. 3-4, pp. 319-325, 2004.

[198] Z. Wu, L. Wang, Y. Jing, X. Li, and Y. Zhao, "Variable volume fed-batch fermentation for nisin production by lactococcus lactis subsp. lactis W28," Applied Biochemistry and Biotechnology, vol. 152, no. 3, pp. 372-382, 2009.

[199] R. Callewaert and L. de Vuyst, "Bacteriocin production with Lactobacillus amylovorus DCE 471 is improved and stabilized by fed-batch fermentation," Applied and Environmental Microbiology, vol. 66, no. 2, pp. 606-613, 2000.

[200] L. de Vuyst, "Nutritional factors affecting nisin production by Lactococcus lactis subsp. lactis NIZO 22186 in a synthetic medium," Journal of Applied Bacteriology, vol. 78, no. 1, pp. 28-33, 1995.

[201] N. S. Egorov, I. P. Baranova, Y. I. Kozlova et al., "A new nutrient medium for Streptococcus lactis producing nizin," Antibiotiki, vol. 25, no. 4, pp. 260-263, 1980.

[202] J. Hugenholtz and G. J. C. de Veer, "Application of nisin A and nisin Z in dairy technology," in Nisin and Novel Lantibiotics, G. Jung and H. G. Sahl, Eds., pp. 440-447, ESCOM Science Publishers B.V., Leiden, The Netherlands, 1991.

[203] L. de Vuyst and E. J. Vandamme, "Influence of the phosphorus and nitrogen source of nisin production in Lactococcus lactis subsp. lactis batch fermentations using a complex medium," Applied Microbiology and Biotechnology, vol. 40, no. 1, pp. 17-22, 1993.

[204] N. P. Guerra and L. Pastrana, "Nisin and pediocin production on mussel-processing waste supplemented with glucose and five nitrogen sources," Letters in Applied Microbiology, vol. 34, no. 2, pp. 114-118, 2002.

[205] B. Bibal, G. Goma, Y. Vayssier, and A. Pareilleux, "Influence of $\mathrm{pH}$, lactose and lactic acid on the growth of Streptococcus cremoris: a kinetic study," Applied Microbiology and Biotechnology, vol. 28, no. 4-5, pp. 340-344, 1988.

[206] B. Poolman and W. N. Konings, "Relation of growth of Streptococcus lactis and Streptococcus cremoris to amino acid transport," Journal of Bacteriology, vol. 170, no. 2, pp. 700707, 1988.

[207] E. W. J. van Niel and B. Hahn-Hägerdal, "Nutrient requirements of lactococci in defined growth media," Applied Microbiology and Biotechnology, vol. 52, no. 5, pp. 617-627, 1999.

[208] O. Kandler and N. Weiss, "Genus lactobacillus Beijerinck 1901," in Bergey's Manual of Systematic Bacteriology, P. H. A. Sneath, N. S. Mair, M. E. Sharpe, and J. G. Holt, Eds., vol. 2, pp. 1209-1243, Williams and Wilkins, Baltimore, Md, USA, 1986.

[209] I. P. Baranova and N. S. Egorov, "Effect of the medium composition and cultivation conditions on the Streptococcus lactis. Growth and nisin biosynthesis," Prikladnaia Biohimiia i Mikrobiologiia, vol. 5, pp. 175-182, 1969.

[210] H. Matsusaki, N. Endo, K. Sonomoto, and A. Ishizaki, "Lantibiotic nisin $\mathrm{Z}$ fermentative production by Lactococcus lactis 10-1: relationship between production of the lantibiotic and lactate and cell growth," Applied Microbiology and Biotechnology, vol. 45, no. 1-2, pp. 36-40, 1996.

[211] E. Parente and C. Hill, "A comparison of factors affecting the production of two bacteriocins from lactic acid bacteria," Journal of Applied Bacteriology, vol. 73, no. 4, pp. 290-298, 1992.

[212] I. P. Baranova and N. S. Egorov, "An effect of various nitrogen compounds on Streptococcus lactis growth and nisin production," Mikrobiologiia, vol. 36, pp. 958-963, 1967.
[213] L. de Vuyst, G. de Poorter, and E. J. Vandamme, "Nutritional and metabolic regulation of the nisin fermentation process," Mededelingen Faculteit Landbouwwetenschappen Rijksuniversiteit Gent, vol. 54, pp. 1501-1506, 1989.

[214] M. L. Cabo, M. A. Murado, M. P. Gonzalez, J. A. Vazquez, and L. Pastoriza, "An empirical model for describing the effects of nitrogen sources on nisin production," Letters in Applied Microbiology, vol. 33, no. 6, pp. 425-429, 2001.

[215] M. Lopez, Nisina: producción y aplicación a la conservación en pescado refrigerado [Ph.D. thesis], University of Santiago de Compostela, Santiago de Compostela, Spain, 1998.

[216] J. Lee, S. Y. Lee, S. Park, and A. P. J. Middelberg, "Control of fed-batch fermentations," Biotechnology Advances, vol. 17, no. 1, pp. 29-48, 1999.

[217] N. P. Guerra, A. T. Agrasar, C. L. Macías, P. F. Bernárdez, and L. P. Castro, "Dynamic mathematical models to describe the growth and nisin production by Lactococcus lactis subsp. lactis CECT 539 in both batch and re-alkalized fed-batch cultures," Journal of Food Engineering, vol. 82, no. 2, pp. 103113, 2007.

[218] R. Luedeking and E. L. Piret, "A kinetic study of the lactic acid fermentation. Batch process at controlled $\mathrm{pH}$," Journal of Biochemical and Microbiological Technology and Engineering, vol. 1, no. 4, pp. 393-412, 1959.

[219] J. A. Vázquez, M. P. González, and M. A. Murado, "Substrate inhibition of Pediococcus acidilactici by glucose on a waste medium. Simulations and experimental results," Letters in Applied Microbiology, vol. 37, no. 5, pp. 365-369, 2003.

[220] F. Leroy and L. de Vuyst, "Growth of the bacteriocinproducing Lactobacillus sakei strain CTC 494 in MRS broth is strongly reduced due to nutrient exhaustion: a nutrient depletion model for the growth of lactic acid bacteria," Applied and Environmental Microbiology, vol. 67, no. 10, pp. 4407-4413, 2001.

[221] N. P. Guerra, P. Fajardo, C. Fuciños et al., "Modelling the biphasic growth and product formation by Enterococcus faecium CECT 410 in realkalized fed-batch fermentations in whey," Journal of Biomedicine and Biotechnology, vol. 2010, Article ID 290286, 16 pages, 2010. 

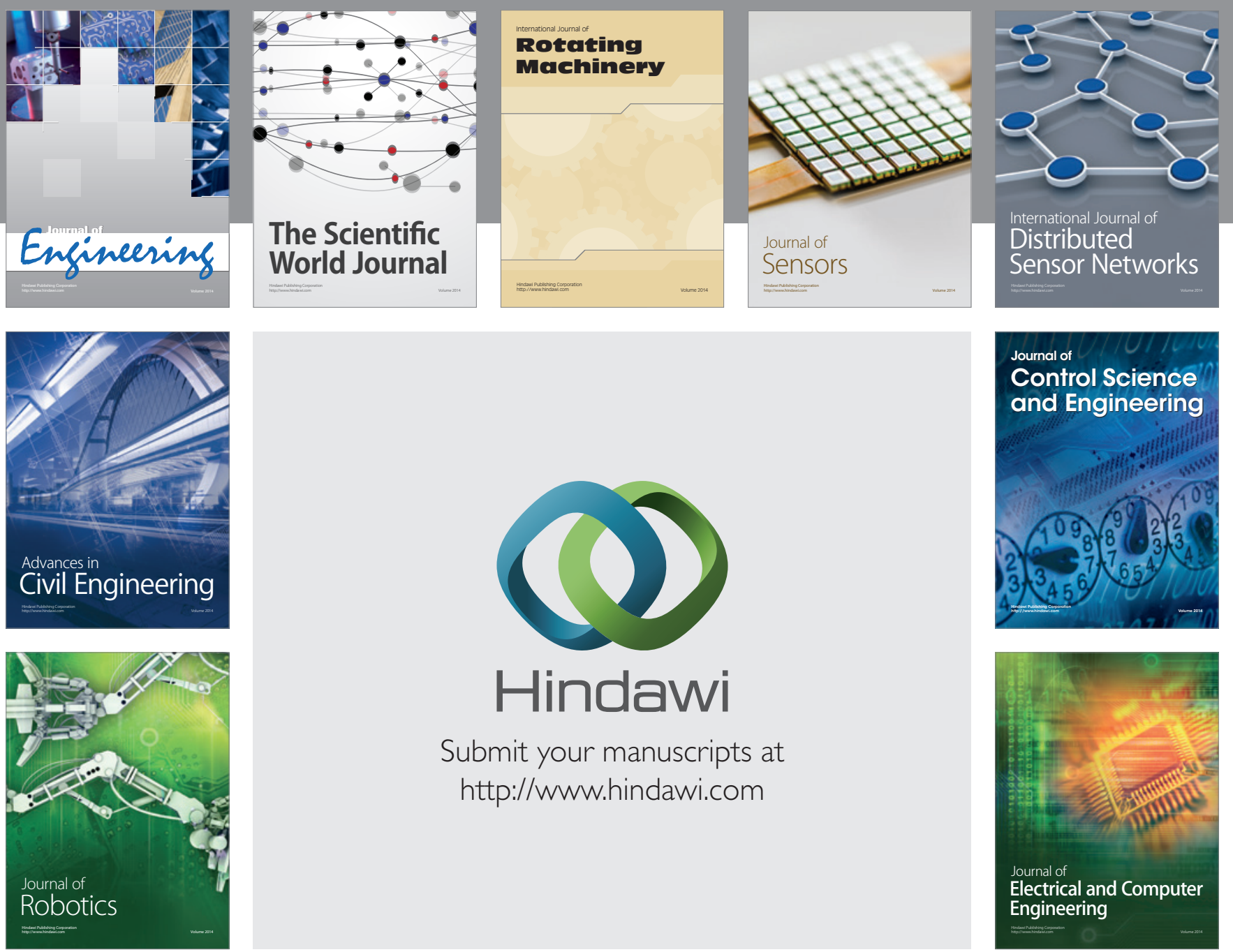

Submit your manuscripts at

http://www.hindawi.com
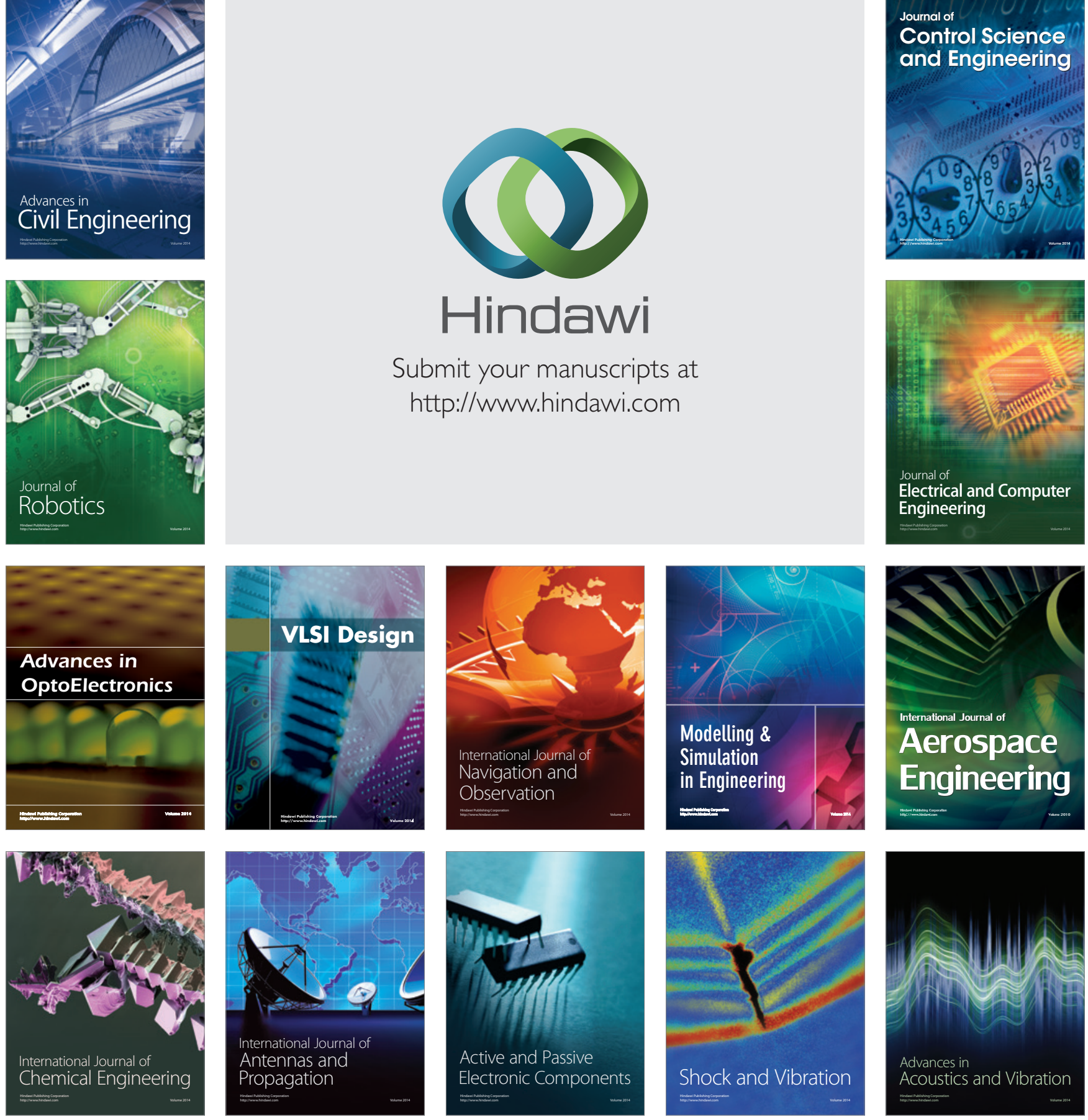